Weiner, Csaba (2020) 'Russian Multinational Direct Investment in East Central European Countries', in Ágnes Szunomár, eds, Emerging-market Multinational Enterprises in East Central Europe, 153-195, Cham: Palgrave Macmillan.

\title{
Russian Multinational Direct Investment in East Central European Countries
}

Csaba Weiner

\begin{abstract}
This chapter assesses the characteristics of Russian outward foreign direct investment (OFDI) and multinationals in general and in particular in five EU-member Central and East European (CEE) states, including Czechia, Hungary, Poland, Slovakia and Slovenia. Besides official statistics, the research relies on company data analysed using Dunning's eclectic paradigm and his typology of four motives. In addition to pull factors, the importance of push factors is emphasised. Weiner finds that Russian FDI in the five CEE countries is dominated by marketseeking and, to a lesser extent, efficiency-seeking projects carried out by state-owned or staterelated private firms. Most Russian FDI has been done in hydrocarbons, iron, steel and machinery, but banking, software solutions, electronic production, real estate and even the light industry have also been targeted.
\end{abstract}

\section{Keywords}

Outward foreign direct investment, Multinational enterprises, Russia, Central and Eastern Europe, Pull factors, Push factors

\subsection{Introduction}

\subsubsection{The Historical Context of Russian OFDI and Multinationals}

Russian multinationals play a very active role in outward foreign direct investment (OFDI). With the exception of 2015, Russia has since 2002 been among the top 20 countries in the world with the largest OFDI stock ${ }^{1}$ (UNCTAD FDI database n.d.).

The history of Russian OFDI dates back to the nineteenth century and covers six main periods. According to Liuhto and Majuri (2014: 211) these include the following: (1) OFDI before the socialist era; (2) the stagnation of OFDI after the Russian Revolution of 1917; (3) the gradual growth of the foreign activities of red multinationals in the period from the end of the 1960s until the dissolution of the Soviet Union in 1991; (4) the emergence of the first real Russian multinationals in 1992-1996; (5) the golden era of Russian multinationals between 1997 and 2008; and (6) the survival or withdrawal of Russian multinationals during and after the global financial meltdown, the Ukrainian conflict and the most recent 2014-2016 crisis (Kari Liuhto, email communication, 27 January 2020). In contrast, Kuznetsov believes that the golden ages began not in 1997, but only sometime in 2002/2003, and marks the ongoing period as 'adaptation to new reality' (Alexey Kuznetsov, email communication, 12 February 2020).

\footnotetext{
${ }^{1}$ Similarly, the acronym for inward foreign direct investment is IFDI.
} 
The actual state of the economy and the changing role of the Russian state have been reflected in Russia's OFDI data. Since the dissolution of the Soviet Union, four crises have shaken the Russian economy: (1) the transformational recession of 1992-1996; (2) the currency, fiscal, debt and banking crisis in 1998; (3) the global financial crisis of 2008-2009; and (4) the crisis of 2014-2016, caused by low oil prices and Western sanctions against Russia over its actions in Ukraine.

Since the early 1990s, the political and economic systems have undergone substantial changes in Russia. The main dividing line was the targeted campaign launched against the Yukos oil company in 2003. State-business relations have changed significantly since that time. Following a largely liberal capitalist system, the state has substantially expanded its role in the economy, and thus an etatist period began (Vasileva 2014). The crises of 2008-2009 and 20142016 have not contributed to a further such significant increase in the role of the Russian state. During Boris Yeltsin's presidency (1991-1999), the Russian state actively contributed to the creation of large private monopolies, giving birth to future multinationals (Kalotay 2008: 98).

In the 1990s, Russian OFDI did exist but it could mostly be regarded as capital flight from an unstable environment to offshore paradises and tax havens (Filippov 2008: 6-8). Due to negative domestic push factors, this kind of OFDI, called an 'exodus' by Vahtra and Liuhto (2004), has appeared from time to time relating to the crisis periods. This is also closely associated with the phenomenon of 'round-tripping' (i.e., FDI leaving the country and returning). The opposite of exodus is 'expansion', which is driven by either international pull ${ }^{2}$ or positive domestic push factors.

According to the data collected by the Central Bank of Russia (CBR), FDI outflows from Russia received a big boost first in 2003 and then in 2006 (Table 6.1). In 2008, they hit a new record high. In the 2000s, the marked rise in international energy and commodity prices led to spectacular developments in resource-based sectors in Russia, encouraging Russian companies to venture abroad (Filippov 2008: 7). The growth of Russian assets abroad has largely been driven by cross-border mergers and acquisitions (Kuznetsov 2013: 7).

The effects of the global financial crisis began to be felt as of the third quarter of 2008 onwards, followed by a significant decline in 2009. Russian metal giants suffered the consequences of the downturn more than Russian oil and gas companies (Kuznetsov 2010a: 12). However, in 2013, Russian FDI outflows stood at a new record level. This impetus was broken when the Russian crisis began in 2014. Russian multinationals have faced constraints in international financial markets. Sanctions against Russian banks financing Russian multinationals came to represent a big threat to Russian OFDI (UNCTAD 2015: 69). Consequently, the year 2015 saw a drastic reduction in Russian FDI flows - in both directions. Moreover, a new Russian anti-offshore law took effect in January 2015, aiming to prevent the cash drain from Russia to offshore centres, the use of cross-border tax evasion schemes and, thus, to reduce round-tripping investment (UNCTAD 2016: 7, 94). However, as during the 2008-2009 crisis, significant acquisitions still took place in 2014-2016 (UNCTAD 2016: 62; 2017: 68). In 2017 and 2018, higher Russian FDI outflows were again reported, but these changes are dependent on whether the asset/liability principle or the directional principle is applied to measure them.

The list of the top 15 Russian non-financial multinationals ranked by foreign assets in 2017 shows that out of these, only six were state-controlled (UNCTAD 2019: 58-59). Russia's leading multinationals have a concentrated ownership structure, with either government supremacy or oligarchic dominance (Liuhto 2016: 260).

\footnotetext{
${ }^{2}$ For international pull factors, we do not use either positive or negative attributes, as we believe that they are positive in themselves.
} 
Table 6.1

FDI outflows from, and inflows into, Russia, according to the CBR, 1994-2018 (millions of dollars)

\begin{tabular}{|c|c|c|c|c|c|c|c|c|c|c|c|c|c|c|}
\hline & 1994 & 1995 & 1996 & 1997 & 1998 & 1999 & 2000 & 2001 & 2002 & 2003 & 2004 & 2005 & 2006 & 2007 \\
\hline \multicolumn{15}{|c|}{ Asset/liability principle } \\
\hline Outflows & 281 & 606 & 923 & 3184 & 1210 & 2195 & 3179 & 2541 & 3533 & 9724 & 13,782 & $\mathbf{1 7 , 8 8 0}$ & 29,993 & 44,801 \\
\hline Inflows & 690 & 2066 & 2579 & 4865 & 2761 & 3286 & 2678 & 2847 & 3474 & 7929 & 15,403 & 15,508 & 37,595 & 55,874 \\
\hline \multicolumn{15}{|c|}{ Directional principle } \\
\hline Outflows & - & - & - & 3184 & 1210 & 2195 & 3152 & 2502 & 3484 & 9550 & 13,663 & 16,747 & 29,840 & 43,849 \\
\hline Inflows & - & - & - & 4865 & 2761 & 3286 & 2651 & 2808 & 3425 & 7755 & 15,284 & 14,375 & 37,442 & 54,922 \\
\hline
\end{tabular}

\begin{tabular}{|c|c|c|c|c|c|c|c|c|c|c|c|}
\hline & 2008 & 2009 & 2010 & 2011 & 2012 & 2013 & 2014 & 2015 & 2016 & 2017 & 2018 \\
\hline \multicolumn{12}{|c|}{ Asset/liability principle } \\
\hline Outflows & 55,663 & 43,281 & 52,616 & 66,851 & 48,822 & $\mathbf{8 6 , 5 0 7}$ & 57,082 & 22,085 & 22,314 & 36,757 & $\mathbf{3 1 , 3 7 7}$ \\
\hline Inflows & 74,783 & 36,583 & 43,168 & 55,084 & 50,588 & 69,219 & 22,031 & 6853 & 32,539 & 28,557 & 8785 \\
\hline \multicolumn{12}{|c|}{ Directional principle } \\
\hline Outflows & 56,735 & $\mathbf{3 4 , 4 5 0}$ & 41,116 & 48,635 & 28,423 & 70,685 & 64,203 & 27,090 & 26,951 & 34,153 & 35,820 \\
\hline Inflows & 75,856 & 27,752 & 31,668 & 36,868 & 30,188 & 53,397 & 29,152 & 11,858 & 37,176 & 25,954 & 13,228 \\
\hline
\end{tabular}

Source: Own compilation based on CBR (2020a, 2020b)

Note: Bold cells indicate years when FDI outflows exceeded FDI inflows

- Not available 


\subsubsection{The Size and Geographical Distribution of Russian OFDI}

For a long time, both the Central Bank of Russia and the Russian Federal State Statistics Service (Rosstat) provided official data on Russian OFDI. However, since 2014, only CBR data have been available. A common feature of these FDI statistics is that they are organised on the basis of the immediate host and investing country, and not according to the ultimate host and investing country. This is particularly problematic as certain third countries, largely de jure or de facto tax havens and offshore centres, play a significant role in intermediating Russian FDI. At a later stage, FDI is trans-shipped to the final target country or round-tripped back to Russia (Kalotay et al. 2014: 6).

According to the CBR based on the directional principle, at the end of 2018, Russia's OFDI stock was USD 344 billion (Table 6.2). Yet, because of round-tripping, both inward and outward FDI are overestimated (Kuznetsov 2017: 78-79). Foreign assets of the top 15 Russian non-financial multinationals reached USD 105.1 billion at the end of 2017 (UNCTAD 2019: 59).

The economic crisis of 2014-2016, the depreciating Russian currency, the 2015 Russian anti-offshore law, various amendments to the tax code and the 2018 creation of inner offshore zones have caused changes in round-tripping and trans-shipping, reflected in IFDI and OFDI stock and flow data relating to intermediary countries, particularly those of Cyprus and the British Virgin Islands (Table 6.3) (UNCTAD 2016: 60; 2019: 56).

The bulk of Russia's OFDI stock is in developed countries (UNCTAD 2016: 12). The most important destinations for Russian OFDI are Europe and the United States (UNCTAD 2015: 69). These observations are based on CBR data.

CBR data show most of Russia's OFDI stock is in Cyprus and the Netherlands, two developed EU countries. However, OFDI stock in the British Virgin Islands, a developing Caribbean economy, statistically part of Latin America and the Caribbean (like the Bahamas and the Cayman Islands), has recently substantially decreased. The role of Latin America and the Caribbean is still very much overstated (Kuznetsov 2017: 79).

By definition, Cyprus and the Netherlands are neither tax havens nor offshore jurisdictions, but in reality, many EU countries-including, for example, Luxembourg-should be historically included into these categories. Moreover, the United Kingdom, Ireland, Austria and Switzerland are also leading 'conduit countries' (Bulatov et al. 2016: 400). ${ }^{3}$

Relying on official statistics, UNCTAD (2017: 68) claims Russian firms have targeted emerging markets moderately. According to these statistics, CIS countries have attracted only minor Russian OFDI, mainly concentrated in Kazakhstan and Ukraine. But based on extensive company-level data, Kuznetsov (2017: 79) argues that besides the West (including primarily the United States and a number of EU members), neighbouring Ukraine, Kazakhstan and Belarus are also among the leading recipients of Russian multinational capital, and thus their role is underestimated.

Likewise, Russian FDI stock in Asia is underreported (Kuznetsov 2017: 81). Kuznetsov (2017: 80) notes the rise in the significance of Turkey, Thailand, some other Asian countries and the members of the Eurasian Economic Union. Russia has also dipped a toe in African waters (Panibratov 2017: 284), but the value of Russian FDI has remained insignificant on that continent, though much higher than official statistics suggest (Kuznetsov 2017: 80-81).

\footnotetext{
${ }^{3}$ In contrast, based on the directional principle, Russian FDI stock in Luxembourg and Ireland is negative (CBR 2019c).
} 
Table 6.2

OFDI stock from, and IFDI stock in, Russia, according to the UNCTAD and CBR, end of period, 1993-2018 (millions of dollars)

\begin{tabular}{|l|l|l|l|l|l|l|l|l|l|l|l|l|l|l|l|l|l|l|l|l|l|l|}
\hline \multicolumn{1}{|l|}{$\mathbf{1 9 9 3}$} & $\mathbf{1 9 9 4}$ & $\mathbf{1 9 9 5}$ & $\mathbf{1 9 9 6}$ & $\mathbf{1 9 9 7}$ & $\mathbf{1 9 9 8}$ & $\mathbf{1 9 9 9}$ & $\mathbf{2 0 0 0}$ & $\mathbf{2 0 0 1}$ & $\mathbf{2 0 0 2}$ & $\mathbf{2 0 0 3}$ & $\mathbf{2 0 0 4}$ & $\mathbf{2 0 0 5}$ \\
\hline UNCTAD
\end{tabular}

\begin{tabular}{|c|c|c|c|c|c|c|c|c|c|c|c|c|c|}
\hline & 2006 & 2007 & 2008 & 2009 & 2010 & 2011 & 2012 & 2013 & 2014 & 2015 & 2016 & 2017 & 2018 \\
\hline \multicolumn{14}{|c|}{ CBR (asset/liability principle) } \\
\hline OFDI & - & - & - & 298,357 & 361,121 & 361,750 & 409,567 & 479,501 & 411,270 & 367,593 & 418,034 & 468,567 & 433,587 \\
\hline IFDI & - & - & - & 377,447 & 488,993 & 454,949 & 514,926 & 565,654 & 371,491 & 347,690 & 477,670 & 529,644 & 498,989 \\
\hline \multicolumn{14}{|c|}{ CBR (directional principle) } \\
\hline OFDI & - & - & - & - & - & - & - & 385,321 & 329,818 & 282,651 & 334,275 & 380,047 & 344,318 \\
\hline IFDI & - & - & - & - & - & - & - & 471,474 & 290,039 & 262,748 & 393,910 & 441,123 & 409,720 \\
\hline \multicolumn{14}{|c|}{$U N C T A D^{\mathrm{a}}$} \\
\hline OFDI & 232,881 & 363,481 & 197,273 & 288,289 & 336,355 & 315,742 & 332,834 & 385,322 & $\mathbf{3 2 9 , 8 1 7}$ & 282,651 & 334,275 & 380,047 & 344,090 \\
\hline IFDI & 263,903 & 488,280 & 212,887 & 367,379 & 464,228 & 408,942 & 438,194 & 471,475 & 290,039 & 262,748 & 393,910 & 441,123 & 407,362 \\
\hline
\end{tabular}

Source: Own compilation based on UNCTAD FDI database (n.d.) and CBR (2019a, 2019b, 2019c, 2019d)

Note: Bold cells indicate years when OFDI stock exceeded IFDI stock

- Not available

aUNCTAD moved to use directional principle data (Kálmán Kalotay, email communication, 22 January 2020) 
Table 6.3

The top 15 host countries for Russian OFDI stock and the top 15 sources of Russia's IFDI stock, according to the CBR, based on the directional principle, end of period, 2013, 2018 (millions of dollars)

\begin{tabular}{|c|c|c|c|c|c|c|c|}
\hline \multicolumn{4}{|c|}{ OFDI stock from Russia } & \multicolumn{4}{|c|}{ IFDI stock in Russia } \\
\hline \multicolumn{2}{|c|}{2013} & \multicolumn{2}{|l|}{2018} & \multicolumn{2}{|c|}{2013} & \multicolumn{2}{|l|}{2018} \\
\hline Cyprus & 152,702 & Cyprus & 172,461 & Cyprus & 183,276 & Cyprus & 126,366 \\
\hline BVI & 74,412 & Netherlands & 40,415 & Netherlands & 48,948 & Netherlands & 40,309 \\
\hline Netherlands & 45,012 & Austria & 26,710 & Bahamas & 31,964 & Bahamas & 39,031 \\
\hline Austria & 25,500 & Switzerland & 17,760 & Bermuda & 29,565 & Bermuda & 29,830 \\
\hline $\begin{array}{l}\text { United } \\
\text { States }\end{array}$ & 20,943 & BVI & 11,277 & $\begin{array}{l}\text { United } \\
\text { Kingdom }\end{array}$ & 21,759 & Luxembourg & 19,561 \\
\hline Switzerland & 12,096 & Bahamas & 8806 & BVI & 18,925 & France & 17,291 \\
\hline Germany & 9607 & Turkey & 8229 & Germany & 18,898 & Germany & 16,410 \\
\hline $\begin{array}{l}\text { United } \\
\text { Kingdom } \\
\end{array}$ & 7901 & Germany & 8125 & United States & 17,979 & $\begin{array}{l}\text { United } \\
\text { Kingdom }\end{array}$ & $\mathbf{1 4 , 9 3 3}$ \\
\hline Bahamas & 6416 & $\begin{array}{l}\text { United } \\
\text { States }\end{array}$ & 7332 & Sweden & 16,176 & Switzerland & 11,029 \\
\hline Ukraine & 5968 & Spain & 6441 & France & 14,075 & BVI & 10,356 \\
\hline Turkey & 5277 & $\begin{array}{l}\text { United } \\
\text { Kingdom }\end{array}$ & 6378 & Luxembourg & 12,780 & Jersey & 9945 \\
\hline Spain & 4772 & Belarus & 3960 & Austria & 11,816 & Ireland & 5824 \\
\hline Jersey & 4128 & Singapore & 3471 & Switzerland & 6040 & Austria & 5604 \\
\hline Belarus & 4089 & Kazakhstan & 3302 & Ireland & 5210 & Italy & 4626 \\
\hline France & 3629 & Ukraine & 3104 & Jersey & 5013 & Sweden & 4531 \\
\hline
\end{tabular}

Source: Own compilation based on CBR (2019a, 2019c)

Note: Bold cells indicate the EU states

$B V I$ British Virgin Islands

\subsubsection{The Role of the $E U$}

According to Kuznetsov (2011: 11), on the eve of the global financial crisis of 2008-2009 and with the development of Russian multinationals, Russian companies have shifted their focus from Europe to other regions. The geographic distribution of foreign assets of the largest Russian multinationals also suggests a constantly decreasing share in Europe (Skolkovo 2007: 12; 2008: 10; IMEMO 2009: 16; 2011: 24; Kuznetsov 2013: 15). Principally, this has long meant the increasing role of North America. Asia and Africa have also received growing attention. The latter fits into the overall logic of Russian internationalisation and is weakly influenced by the foreign political events of the mid-2010s. However, a radical turn toward the East is impossible. The recent increase in the share of some Asian countries has been due to the exit of a number of Russian investors from the United States and Ukraine, as well as a reduction in the weight of the Caribbean offshore world, rather than the devaluation of the role of the EU (Kuznetsov 2017: 79-80). According to Bulatov et al. (2016: 409), due to the Eurasian Economic Union, growth opportunities are greater in Belarus and Kazakhstan than in the United States.

The gradual reduction of non-CIS Europe's role in favour of North America (the increasing role of the United States, however, has been stopped and reversed) and the developing countries has indicated the evolution of Russian multinationals from regional and bi-regional to real global ones (Kuznetsov 2011: 13). Russian multinationals typically begin their international expansion in other CIS countries (Panibratov 2017: 284). However, UNCTAD (2017: 68) warns that projects in emerging economies do not allow Russian multinationals the same access to cutting-edge technologies as in traditional advanced countries.

Eurostat and the CBR display very different data on the size of Russian FDI in the EU. Both $\mathrm{CBR}$ and Eurostat statistics are consistent with the methodology set out in the 6th edition of the 


\section{Table 6.4}

Comparing Russian FDI stock in the EU countries using different methodologies, end of period (millions of dollars and millions of euros)

\begin{tabular}{|c|c|c|c|c|c|c|}
\hline & \multicolumn{2}{|c|}{ Eurostat (millions of euros) } & \multicolumn{3}{|c|}{$\begin{array}{l}\text { CBR (directional principle) (millions of } \\
\text { dollars) }\end{array}$} & \multirow{2}{*}{$\begin{array}{l}\begin{array}{l}\text { IMEMO } \\
\text { (millions of } \\
\text { dollars) }\end{array} \\
2016 \\
\end{array}$} \\
\hline & 2016 & 2017 & 2016 & 2017 & 2018 & \\
\hline Total & & & 334,275 & 380,047 & 344,318 & \\
\hline EU28 & 72,809 & 83,381 & 220,892 & 260,668 & 256,638 & - \\
\hline \multicolumn{7}{|c|}{ EU15 plus Cyprus and Malta } \\
\hline Austria & $\_^{(\mathrm{c})}$ & $-(\mathrm{c})$ & 21,690 & 30,944 & 26,710 & $1590^{\mathrm{a}}$ \\
\hline Belgium & 112 & -141 & 437 & 527 & 679 & $1470^{\mathrm{a}}$ \\
\hline Cyprus & 33,656 & 33,620 & 141,508 & 175,217 & 172,461 & $50^{\mathrm{a}}$ \\
\hline Denmark & 102 & 49 & 1028 & 1205 & 1214 & - \\
\hline Finland & 986 & 1111 & 2923 & 3035 & 2829 & $1580^{\mathrm{a}}$ \\
\hline France & 1635 & 1980 & 2806 & 3006 & 2979 & $1680^{\mathrm{a}}$ \\
\hline Germany & 3832 & 2318 & 7560 & 8411 & 8125 & $11,690^{\mathrm{a}}$ \\
\hline Greece & 26 & 31 & 683 & 733 & 668 & - \\
\hline Ireland & 2298 & 2003 & $-17,955$ & $-19,849$ & $-12,510$ & $560^{\mathrm{a}}$ \\
\hline Italy & 145 & 560 & 2476 & 2816 & 2775 & $16,160^{\mathrm{a}}$ \\
\hline Luxembourg & $-38,774$ & $-27,568$ & $-20,048$ & $-19,104$ & $-12,113$ & $10^{\mathrm{a}}$ \\
\hline Malta & 44 & 50 & 96 & 126 & 122 & - \\
\hline Netherlands & 36,619 & 29,188 & 53,808 & 48,493 & 40,415 & $1060^{\mathrm{a}}$ \\
\hline Portugal & 146 & 171 & 223 & 228 & 231 & - \\
\hline Spain & 6968 & 7499 & 6321 & 6382 & 6441 & $220^{a}$ \\
\hline Sweden & 179 & 58 & 167 & 183 & 173 & - \\
\hline $\begin{array}{l}\text { United } \\
\text { Kingdom }\end{array}$ & 1172 & 1014 & 8687 & 9091 & 6378 & $7900^{a}$ \\
\hline \multicolumn{7}{|c|}{ EU-member CEE countries (EU11) } \\
\hline Bulgaria & 2042 & 2035 & 3244 & 3330 & 3103 & $4020^{\mathrm{a}}$ \\
\hline Croatia & 302 & 331 & 388 & 531 & 529 & - \\
\hline Estonia & 751 & 747 & 348 & 328 & 369 & - \\
\hline Latvia & 1334 & 1538 & 1361 & 1546 & 1599 & $880^{\mathrm{a}}$ \\
\hline Lithuania & 274 & 261 & 303 & 315 & 323 & - \\
\hline Romania & 139 & 68 & 30 & 29 & 31 & $1570^{\mathrm{a}}$ \\
\hline \multicolumn{7}{|c|}{ of which ECE countries } \\
\hline Czechia & 613 & 715 & 1790 & 1791 & 1824 & 932 \\
\hline Hungary & -62 & 42 & 253 & 259 & 279 & 165 \\
\hline Poland & 306 & 370 & 452 & 666 & 538 & 1144 \\
\hline Slovakia & -214 & -173 & 129 & 161 & 160 & 89 \\
\hline Slovenia & 70 & 176 & 184 & 270 & 309 & 140 \\
\hline \multicolumn{7}{|c|}{ Non-EU-member CEE countries } \\
\hline Albania & $-^{(\mathrm{c})}$ & $-^{(\mathrm{c})}$ & 5 & 5 & 6 & - \\
\hline $\begin{array}{l}\text { Bosnia and } \\
\text { Herz. }\end{array}$ & - & - & 615 & 665 & 670 & - \\
\hline Kosovo & $0^{\mathrm{a}}$ & $0^{\mathrm{a}}$ & - & - & - & - \\
\hline Montenegro & $-^{(\mathrm{c})}$ & $-(\mathrm{c})$ & 1335 & 1366 & 1396 & - \\
\hline $\begin{array}{l}\text { North } \\
\text { Macedonia }\end{array}$ & 39 & 27 & 5 & 9 & 12 & - \\
\hline Serbia & 1355 & - & 1369 & 1567 & 1547 & $2550^{\mathrm{a}}$ \\
\hline
\end{tabular}

Source: Own compilations based on Eurostat (2019), CBR (2019c), EABR (2017: 24) and IMEMO's database

- Not available

- $^{(\mathrm{c})}$ Confidential

${ }^{\text {a It }}$ is rounded by the author

IMF's Balance of Payments and International Investment Position Manual (BPM6). Differences in data are in large part a result of the activities of special-purpose entities (SPEs). For end-2017, Eurostat reported Russian FDI stock in the EU28 of EUR 83.4 billion. By 
comparison, ${ }^{4}$ a simple accumulation of country data from the CBR suggests the size of Russian FDI in the EU28 amounted to USD 260.7 billion at the end of 2017 (and USD 256.6 billion at the end of 2018) (Table 6.4). At the end of 2017, Russia's share in the EU28's total IFDI stock by extra-EU28 investing countries was only 1.3 per cent (Eurostat 2019). In contrast, according to the CBR, the EU28's share in Russia's OFDI stock accounted for 68.6 per cent at the end of 2017 (and 74.5 per cent at the end of 2018) (CBR 2019c). The EU's significance for Russia is incontestable, even if we exclude some of the trans-shipment transactions and all the cases of round-tripping.

Stock data from Eurostat (2019) show that at the end of 2017, the largest recipients of Russian FDI in the EU were Cyprus, the Netherlands, Spain and Germany. However, statistics also indicate that Russian FDI stock in the Netherlands is related to the activities of SPEs and the situation should be similar for Cyprus for which SPE data are not available. According to data from the CBR (2019c), Russian FDI stock in the EU at the end of 2018 was by far the largest in Cyprus, followed by the Netherlands, Austria, Germany, Spain and the United Kingdom.

Using a different methodology, IMEMO's FDI project database, incorporating projects for which FDI stock exceeds USD 3 million, perhaps gives a much more accurate picture than official data. Accordingly, at the end of 2016, the main destinations in non-CIS Eurasia were Italy, Germany, Great Britain, Turkey, Switzerland, Iraq and Bulgaria. This database shows minor Russian FDI stock in Cyprus. Likewise, real Russian FDI presence is much smaller in Luxembourg, Spain, Ireland, Latvia and the Netherlands than officially registered (EABR 2017: 24).

\subsubsection{Industrial Distribution of Russian OFDI}

The CBR does not provide data on the sectoral distribution of Russian OFDI, while Rosstat reports only flow data containing information up until 2013. In the period between 2005 and 2013, these data suggest that manufacturing as well as wholesale, retail and repair sectors tended to attract the most Russian OFDI, leaving only minor shares for the financial sectors (Rosstat 2009, 2014). Following a different classification, one can see that among the top 20 or 25 Russian multinationals, oil and gas as well as metallurgy are predominant. In the service sector, infrastructural companies occupy a dominant position (Bulatov et al. 2016: 405). Between 2004 and 2008, the role of oil and gas declined, but increased again in 2009 and 2011 (Skolkovo 2007: 10; 2008: 8; IMEMO 2009: 15; 2011: 22; Kuznetsov 2013: 19). Out of the 15 leading non-financial Russian multinationals ranked by foreign assets in 2017 , four were in metallurgy, four in oil and gas, two in transportation and one in chemicals and one in nuclear energy. Three leading Russian multinationals are conglomerates (UNCTAD 2019: 59). In contrast, the industrial distribution is much more diverse in the second echelon of Russian multinationals (Bulatov et al. 2016: 405). In Europe, Asia and Africa, the sectoral distribution of Russian OFDI is quite diversified, while in North America, Russian FDI has mainly been delivered by metallurgical multinationals (Kuznetsov 2010b: 28; 2017: 82). According to IMEMO's FDI project database, in non-CIS Eurasia, at the end of 2016, most Russian OFDI stock was directed at oil and gas (34.3 per cent), communication and IT (19.7 per cent) and finance (12.9 per cent). Ferrous metals have witnessed the most noticeable decline in their share of the Russian OFDI stock (EABR 2017: 22).

According to Eurostat (2019), the service sector accounted for 80.7 per cent of Russian FDI stock in the EU at the end of 2016. The electricity, gas, steam and air conditioning supply sector

\footnotetext{
${ }^{4}$ End-2018 data are not available from Eurostat.
} 
(4.0 per cent) and private real-estate activities (3.3 per cent) are still also worth mentioning. Foremost among service sectors are financial and insurance activities (47.9 per cent), though professional, scientific and technical activities (22.4 per cent) play a notable role as well. However, in our view, this gives a distorted picture due to SPEs and transactions via third countries.

\subsection{Push and Pull Factors Driving Russian OFDI}

Domestic push and international pull factors are equally important when examining the motives behind Russian OFDI. As already discussed, an exodus is caused by negative domestic push factors, while expansion might be related to either international pull or positive domestic push factors. Thus, while exodus refers to a negative phenomenon, the effect of the home country is not necessarily negative.

\subsubsection{Push Factors}

Russian multinationals challenge some of the premises of traditional FDI theorems (Kalotay et al. 2014), but Dunning's eclectic paradigm or Ownership-Location-Internalisation (OLI) of international production can fit them. The question is whether the role of the Russian state and the Russian economic-policy environment in prompting OFDI can be assimilated under transaction-based ownership-specific advantages $(\mathrm{Ot})$, or a home-country factor $(\mathrm{H})$ has to be added to the OLI legs to OLIH. Kalotay and Sulstarova (2010: 137-138), following Kalotay (2008: 102-103), recommend the latter. Similarly, Anwar and Mughal (2014: 15) argue that Russian OFDI follows the eclectic paradigm to a certain extent, but home-country factors also play a significant role. Kalotay (2010b: 40) divides home-country advantages into the following four groups: home-country-based competitive advantages $(\mathrm{Hc})$, business-environment advantages $(\mathrm{Hb})$, development-strategy advantages $(\mathrm{Hd})$ and state-involvement advantages (Hs).

Home-country-based competitive advantages refers to monopolistic or oligopolistic advantages (a positive domestic push factor accompanied by expansion), arising from dominant positions in the home market. These advantages have often been supported by home-country policies, promoting the formation of national champions (Kalotay 2010b: 40, 42, 45). Notwithstanding, high monopolisation or oligopolisation of the Russian economy frequently drives medium-sized local companies not affiliated with regional or federal authorities to go abroad (a negative domestic push factor accompanied by exodus) (Bulatov 2017: 84-85).

The home-country business environment can be either an advantage or a disadvantage for the company. As a positive effect (an advantage, i.e., a positive domestic push factor), one can refer to an expansion, while in a bad business environment (a disadvantage, i.e., a negative domestic push factor) an exodus is experienced. However, due to a bad Russian business environment, Russian firms possess such firm-specific ownership advantages which can be used abroad (Kalotay 2015: 245).

Home-country development-strategy advantages are linked to the methods and strategies that were applied during the transformation. In Russia, these were based on the building up of national champions, a sustained resistance to IFDI, especially in strategic industries, and an increasing emphasis on promoting OFDI (Kalotay 2010b: 46). The development strategy can also be either a positive or a negative domestic push factor. It is negative if the development strategy is misleading or unsuccessful (Kálmán Kalotay, email communication, 9 July 2015). 
State-involvement advantages are related to government policies towards OFDI and state ownership in outward investing firms. Regarding the former, the shift from reservation through acceptance towards some kind of promotion came later in Russia. As to the latter, a tendency towards more state ownership and intervention can clearly be observed (Kalotay 2010b: 4748). Concerning the state involvement, it is difficult to imagine a negative domestic push factor. Disadvantages that may be experienced while expanding abroad should not be confused with this.

\subsubsection{The Russian State's Role in Promoting Foreign Expansion}

Since the beginning of the 2000s, Russian state leaders have increasingly started to look at OFDI more favourably (Skolkovo 2009: 6). The first real sign of this change was President Vladimir Putin's speech at the 11th St. Petersburg International Economic Forum in June 2007, where he said they were interested in increasing Russian investment abroad and swapping assets with international partners on mutually beneficial terms (Deloitte 2008: 36). The first time Dmitry Medvedev (then first deputy prime minister) spoke about this issue was the speech in Krasnodar in January 2008. He urged Russian companies to copy the Chinese way, claiming that this would reduce dependence on foreign technology, boost production culture, grant the opportunity to diversify investments and win new markets (Belton 2008). However, in October 2009, Medvedev adopted a somewhat different tone, expressing concern over outward foreign investment at a time when the domestic economy was in trouble. Medvedev's concerns were probably fuelled by fear of the political and social consequences of domestic closures and redundancies. In contrast, when Medvedev (as prime minister) offered financial help to Russian steel producers in December 2013, there was no sign of negative governmental attitudes towards foreign assets. The negative attitude regarding OFDI has reportedly been maintained by Putin, including blocking some foreign projects. Nevertheless, launched in 2012, Putin's deoffshorisation campaign is not directed to OFDI but is targeting the ownership of Russian assets or assets with a Russian beneficial owner in foreign jurisdictions (Fortescue and Hanson 2015: 296-296).

Nevertheless, unlike China, there is no specific going-global strategy in Russia (Nestmann and Orlova 2008: 2). Contrary to the Chinese case, Russian outward expansion is mainly driven by private companies (Skolkovo 2009: 6). State support for Russian multinationals is quite weak due to the lack of developed policy instruments. An example for such state support is, nonetheless, the Russian Agency for Export Credit and Investment Insurance (EXIAR), Russia's first-ever such agency, assisting multinationals with export credits and OFDI, which was founded only in late 2011 (Panibratov 2017: 44). In 2013, EXIAR launched a program to insure Russian outward investment against non-commercial risks (Kuznetsov 2014: 130). Here, one can also mention that Russian embassies regularly provide crucial information for Russian companies to establish initial contacts with foreign companies (Panibratov 2017: 43). Additionally, in a broader sense, the Russia-initiated Eurasian Economic Union is a rare example of government measures that promotes comprehensive support for Russian OFDI. Outside the CIS, the Russian government supports and protects only a few dozen Russian multinationals. Real incentives are still lacking for Russian medium-sized multinationals to engage in OFDI (Kuznetsov 2013: 9-10).

Government involvement can be either an advantage or a disadvantage, but it is an important determinant of the success of internationalisation (Panibratov 2013: 5). State-owned companies enjoy many advantages that can help their internationalisation. Such benefits include financial capabilities, access to loans and administrative support (Panibratov and Kalotay 2009: 3). Good diplomatic relations can be used when expanding abroad. A strong but 'grey' tool is international lobbyism for a company (Panibratov and Michailova 2019). Finally, state ownership can offer a kind of guarantee when participating in a risky project and during a crisis. 
On the other hand, government involvement in itself can be a disadvantage when expanding into other states, and, in particular, it may have a negative impact during international political conflicts (Kalotay 2010a: 125).

The influence of the Russian state on fully or partially private companies is also often significant (Panibratov 2013: 9; Kalotay 2015: 254). This was evident in the case of bailouts during the 2008-2009 crisis and is also apparent in the acquisition of assets that gives the Russian government an important strategic advantage (Kalotay 2015: 255).

Nonetheless, the role of the state in the expansion of Russian companies is, on the one hand, overestimated (in the case of natural-resource-based sectors) and, at the same time, underrated (in the case of the relatively small companies in less resource-oriented sectors) (Panibratov 2013). According to Panibratov (2013: 14), the state's interest focuses on the expansion of two types of Russian multinationals: those where the business itself requires strict control (such as in the case of nuclear energy) and where foreign policy necessitates it (such as in defence). These are state-owned companies. A special case is apparent when a private Russian multinational is oriented by the Russian government that favours certain countries, especially the CIS, partly because of enduring political ties and informal networks (Liuhto 2015; Panibratov 2017: 43; Panibratov and Michailova 2019). Meanwhile, Kuznetsov (2013: 5) argues that although some natural-resource-based private companies are politically linked to the Kremlin by personal contacts, their foreign activity is rarely affected by Russian economic diplomacy. Similarly, regarding the largest Russian steel producers, Fortescue and Hanson (2015: 296) do not see any indication of intentions to serve Russia's foreign policy. Likewise, Tepavcevic (2013: 206-207) finds that business interests prevail over Russian national interests in most instances of Russian OFDI. Russian companies do not follow the official Russian foreign policy reflecting broader national interests.

\subsubsection{Pull Factors}

In general, the (pull) motives behind Russian OFDI are typically resource-seeking and marketseeking. One can also observe strategic-asset-seeking FDI, and this motive is especially present among Russian machinery companies outside the top 20 Russian multinationals (Kuznetsov 2013: 3). According to Kuznetsov (2013: 4), efficiency-seeking FDI is more typical for medium-sized Russian multinationals. Finally, image-building and aspirations to achieve better global recognition are also decisive in Russian expansion (Panibratov and Kalotay 2009: 3).

In the EU, the most important motives of Russian multinationals consist of sales promotion, access to, and retention of, markets. Most Russian multinationals are major exporters, while the EU is Russia's main trading partner. Compared to the domestic market and developing countries, Russian OFDI investors note the poor prospects in Western Europe and Central and Eastern Europe $(\mathrm{CEE})^{5}$ for access to raw materials and increasing efficiency by lower labour costs (Kuznetsov 2011: 10). According to Kuznetsov (2011: 10), the role of strategic-assetseeking FDI (access to new technologies or the development of cross-border production chains) is small, though it would be important for the modernisation of the domestic economy. Russian energy multinationals have headed towards the vertical integration of supply chains (oil companies by purchasing foreign refineries and filling stations, while the state-controlled gas giant Gazprom by investing in infrastructure). However, this direction has recently been challenged. In the oil sector, Lukoil, Russia's biggest non-state oil producer, has sold a part of its European downstream assets and Rosneft, Russia's state oil champion, has also downsized

\footnotetext{
${ }^{5} \mathrm{We}$ argue that CEE consists of 17 countries listed in Table 6.4. As in the other chapters of this volume, East Central Europe (ECE) refers to five CEE countries, including Czechia, Hungary, Poland, Slovakia and Slovenia.
} 
its European investment programmes. In the gas sector, the creation of the single gas and electricity markets in the EU (including the EU's Third Energy Package) and ambitious climate governance constitute an abrupt transformation of a long-standing model of cooperation between Russia and the West (Deák 2017).

Many Russian metallurgical multinationals tend to have research and development centres in Europe, but their research and development spending has been very small, and technology transfer has been more frequent in North American plants (Kuznetsov 2011: 10-11). Russian steel exporters are subject to import regulation and market protection on the EU market. With Russia's accession to the WTO in 2011, EU quotas for Russian steel products ceased to exist, though Russia had not fully utilised the quotas even before that. Nevertheless, anti-dumping procedures continue to be a problem for Russia in the EU.

Kuznetsov (2011: 11) claims that it was common for Russian multinationals to strengthen their position in the EU before listing their shares or depositary receipts on European stock exchanges. More concretely, Russian companies bought subsidiaries in the EU in 2006-2007 to make their initial public offering (IPO) abroad comfortably (Alexey Kuznetsov, email communication, 4 December 2015). The motive of attracting much cheaper sources of financing as compared to domestic funds was typical for the period prior to the 2008-2009 crisis, owing to the underdeveloped domestic stock market. In contrast, today, the EU's sanctions against Russia over its actions in Ukraine limit access to EU primary and secondary capital markets for certain Russian banks and companies. Finally, for many Russian multinationals, the EU is still attractive because of its political stability, treated as a means to secure themselves against the possible nationalisation of assets in Russia (Kuznetsov 2011: 11).

\subsection{Patterns and Trends of Russian FDI and Multinationals in ECE Countries}

CBR statistics show that at the end of 2018 Bulgaria was the largest host country of Russian FDI stock within CEE at USD 3.1 billion, followed by Czechia (USD 1.8 billion), Latvia (USD 1.6 billion), Serbia (USD 1.5 billion) and Montenegro (USD 1.4 billion). The CEE region accounted for 3.7 per cent of the Russian OFDI stock, while ECE countries accumulated only 0.9 per cent (CBR 2019c). Thus, Russian official statistics indicate they played a minor role. Only Czechia held a relatively larger Russian FDI stock as of end-2018. Poland, Slovakia, Hungary and Slovenia combined have attracted less Russian FDI than Czechia alone. However, as compared to CBR data, IMEMO calculates much lower Russian FDI in Czechia but much higher in Poland (Table 6.4) (EABR 2017: 24). At the end of both 2009 and 2010, Hungary took a leading position in CEE in terms of attracting Russian FDI. This proved to be temporary and was only due to one item, that is, the acquisition of shares in the Hungarian oil and gas company Mol by Russia's Surgutneftegaz, Russia's third-largest oil producer. Due to local resistance to the 2009 takeover, Surgutneftegaz sold the stake to the Hungarian government in 2011.

\subsubsection{Poland}

Russia is a surprisingly small investor in Poland, despite the common economic heritage and geographic proximity of the two countries and also despite the fact that Poland was the second main destination of Russian OFDI behind the United States in 1995-1999 (Kalotay 2003: 1113). 
Russian oil and gas as well as metal multinationals have been represented in Poland through the FDI activities of Gazprom, Lukoil and Severstal. However, Lukoil divested its downstream assets in 2016.

Gazprom's main interest in Poland is its ownership in EuRoPol GAZ joint venture, the owner of the Polish section of the Yamal-Europe gas pipeline, running from Russia to Germany across Belarus and Poland. EuRoPol GAZ was formed in 1993 to design, construct and operate the Polish pipeline section. Yamal-Europe was commissioned in 1999, following which Poland became an important gas transit country.

In addition to the midstream business, Gazprom has a new market in Poland, since it is attempting to promote the use of natural gas - both compressed and liquefied natural gas (CNG and LNG) - as a fuel for vehicles in Europe. Gazprom's expansion has been achieved in different ways, such as through the development of its own filling stations, through supplying other filling stations and through specific joint projects; the latter are related to LNG-powered buses in Olsztyn and Warsaw.

Lukoil opened its first petrol station in Poland in 1996 and owned 116 Polish units when it sold its fuel retail businesses in Lithuania, Latvia and Poland in 2016 (petrolnet.pl 2016). By that time, Lukoil had already withdrawn from the Czech, Hungarian and Slovakian markets.

Severstallat, the Latvian subsidiary of Russia's largest steel company Severstal, controlled by billionaire Alexey Mordashov, established the pipe producer and steel distributor Severstallat Silesia in Poland in 2008 (called Severstal Distribution since 2014), when Severstallat acquired the assets of the Polish Technologie Buczek, including four pipe mills, two longitudinal cutting lines, a 50.72 per cent stake in Buczek Automotive (a producer of stock for car exhaust silencers) and a 100 per cent stake in Przedsiębiorstwo Usług Transportowych Samkol (a transportation company). These companies employed a total of 260 people at that time (Severstal 2008). Severstallat argued that Poland was an important market with high growth rates, and also that it was a net importer in the flat products segment because domestic production did not meet demand. Severstallat planned for the service centre in the Polish city of Sosnowiec to serve customers within a radius of around 300 kilometres, including in Czechia and Slovakia (Puls Biznesu 2008).

Besides resource-based companies, software and information technology constitute another important part of Russian FDI in Poland, including the activities of Luxoft and Kaspersky Lab. Luxoft is a leading global provider of software development services and IT solutions, controlled by Anatoly Karachinsky's IBS Group. Luxoft has experienced dynamic expansion in Poland. It has offices in Krakow (2010), Wrocław (2013, 2015), Gdańsk (2015) and Warsaw (2016). Krakow holds the highest position in terms of employment in the business services industry in Poland (wnp.pl 2014). Wrocław was chosen because of its great location, reasonable costs, the quality of living, easy access to highly qualified IT staff and (local) government support (Gazeta Wrocławska 2015; Luxoft n.d.). Very similar factors attracted Luxoft to Krakow and Gdańsk. Warsaw was selected so as to keep track of legislative decision-making and vital business processes. Luxoft emphasised that Warsaw also had a vast talent pool of seasoned programmers and numerous cultural and geographic benefits (Luxoft 2016). Thus, in addition to market-seeking, efficiency-seeking motives are also vital in Poland (Kalotay et al. 2014: 17). Furthermore, political stability and strong rule of law, strengthened by EU membership, were also important factors (Gera 2013). In 2016, Luxoft had over 2000 employees in Poland (Gazeta Wyborcza 2016).

Kaspersky Lab is a well-known cybersecurity and anti-virus software provider, owned by ex-Soviet intelligence officer Eugene Kaspersky. Through Kaspersky Lab Polska, Kaspersky Lab has been active in Poland since 2001. It has two offices - in Warsaw and Częstochowa, employing a total of more than 50 specialists (Kaspersky n.d.). 
Russia's Ekoton represents the engineering sector. It has been operating in Poland since 1998 and serving clients throughout the country and abroad. Ekoton focuses on assisting in applications for integrated pollution prevention and control (IPPC) permits, as well as preparing environmental impact assessments (EIA), ecological/environmental audits, Natura 2000 reports, environmental programs, asbestos removal plans and regional development strategies, including tourism development strategies (Prusińska 2010; Ekoton n.d.-b). Ekoton currently has plants in Russia, Ukraine and Poland, producing equipment for wastewater treatment (Ekoton n.d.-a).

Finally, it is important to mention the 2013 acquisition of the vodka producer and spirits distributor Central European Distribution Corporation (CEDC) of Poland by the Russian Standard Corporation. Russian Standard claimed that they had greater potential as one large company, with complementary brands, segments, import portfolios and export markets (Roust 2013).

In addition to these, Poland has also been the target of a couple of unsuccessful takeover attempts made by Russian firms.

\subsubsection{Czechia}

It is estimated that there are some 20,000 firms operating in Czechia that have a Russian owner, but the overwhelming majority of them are rather insignificant. ${ }^{6}$ Although Russia's share in the IFDI stock of Czechia is small, there are several important companies that are in Russian hands.

Regarding the oil and gas sector, Gazprom is involved in different segments of the Czech gas sector. Through its Czech subsidiary Vemex, it supplies final gas and electricity customers, owns public CNG stations, supplies CNG stations controlled by independents and co-owns an underground gas storage facility in Damborice. The latter was put into operation in 2016 and was to be used both to meet demand fluctuations and to support the functions of the trans-Baltic Sea Nord Stream, as well as Germany's Jagal and Opal gas pipelines (Gazprom Germania 2015). Vemex minority shareholder MND, owned by Czech tycoon Karel Komarek's KKCG investment group, is Gazprom's partner in the joint venture Moravia Gas Storage. Gazprom was also engaged in the Czech gas wholesaler Gas-Invest, which was liquidated and then terminated in 2011.

In contrast, Lukoil has not been successful in Czechia. Lukoil has already left the Czech retail fuel market twice. In 2003, it sold its three petrol stations. Between 2006 and 2014, Lukoil again owned petrol stations in Czechia, after it had acquired a network of 44 petrol stations at the end of 2006 (E15.cz 2014). Lukoil was also a jet fuel supplier through the company Lukoil Aviation Czech, founded in 2007 and ultimately terminated in 2016.

Russia holds a strong position in the Czech steel sector. Controlled by Roman Abramovich, Alexander Abramov and Alexander Frolov, Evraz, a major metallurgical and mining company, bought the Czech Vítkovice Steel, a manufacturer of rolled steel products, during the privatisation process conducted in 2005 through its Cyprus-registered subsidiary Mastercraft. Vítkovice Steel took on the new name Evraz Vítkovice Steel (EVS). The aim of entering the 'closed' European market was said to be the motivation behind this acquisition. Evraz sought to increase its market share, secure its client base and acquire additional margins from the sale of higher value-added steel products (Evraz 2005; Krainová 2005). Subsequently, the company grew for a few years, but was severely affected by the 2008-2009 crisis. In 2014, a private

\footnotetext{
${ }^{6}$ Such information is available in an unpublished Czech country study by the Prague Security Studies Institute, prepared for the project "Raising awareness of Russian soft power in Central Europe" (2016-2017), supported by the US National Endowment for Democracy (http://www.pssi.cz/russia-s-influence-activities-incee/kremlinleverage).
} 
investor group, including five Cyprus front companies, bought EVS (Helmer 2014). In 2007, EVS acquired the Czech company Nikom, which converts vanadium oxide produced by Russia's Evraz Vanady Tula into ferrovanadium, used by the steel industry worldwide. Renamed to Evraz Nikom in mid-2012, the company has been in the hands of the Luxembourg Evraz Group since the end of 2012.

In 2004, the year of Czechia's accession to the EU, OMZ, whose principal shareholder is Gazprombank, ${ }^{7}$ acquired three Skoda Holding subsidiaries: Skoda Jaderne Strojirenstvi (Skoda JS), a supplier of technologies for the nuclear power industry; Skoda Hute, a company with a focus on the production of steel and pig-iron forgings; and Skoda Kovarny, a dominant world leader in the manufacture of four-stroke diesel motor cranks and wind power station shafts (New Europe 2004). The related technology and easier access to East European markets were reportedly the reasons behind the Russian industrial group entering the Czech market (Power Machines 2004). In comparison to the highly profitable Skoda JS, Skoda Hute and Skoda Kovarny were subsidiaries that did not bring in much profit and instead incurred debt. In 2007, the latter two were merged and renamed Pilsen Steel, which was finally bought in 2010 by the Luxembourg-registered United Group, established in 2008, with an operating office in Moscow and belonging to Russian investor Igor Shamis. At the time, the share of Russian orders of Pilsen Steel was less than 15-20 per cent, which the new owner wanted to increase (Pilsen Steel 2010). Skoda JS has a branch in Slovakia (see Sect. 6.3.4), and holds ownership stakes in the Czech ÚJV Řež (concentrating primarily on design and engineering, supporting the safe and efficient operation of nuclear and classical power plants, fuel-cycle chemistry, as well as on providing complex services for radioactive waste management) and the Russian MKHO Interatomenergo (providing services for the design, installation and maintenance of integrated security systems). In 2007, OMZ acquired the Brno-based Cheteng Engineering (formerly Chepos), active in engineering services in crude oil and gas refining. However, Cheteng ended in liquidation.

In addition, Russian FDI investors have been engaged in a couple of other important FDI projects in the Czech machinery sector. The first foreign assets of ChTPZ Group (Chelyabinsk Tube-Rolling Plant) or ChelPipe, controlled by Andrei Komarov, was MSA, a manufacturer of pipeline valves in Czechia, which ChelPipe's asset manager, the Luxembourg-based Arkley Capital, acquired in 2006 (New Europe 2006). MSA was important for ChelPipe as MSA's products meet the needs of Russian companies operating trunk pipelines (MetalTorg.ru 2006).

Urals Mining and Metals Company (UMMC, also known as UGMK according to its Russian acronym) acquired a 51 per cent stake in the Czech aircraft manufacturer Aircraft Industries, formerly LET Kunovice, in 2008, which it increased to 100 per cent in 2013. Established in 1999, UGMK is a top Russian producer of copper, zinc, coal, gold and silver. Its principal owner is Iskander Makhmudov. Aircraft of the L 410 series are Aircraft Industries' main products. It also deals with the service and maintenance of L 410 aircraft, selling spare parts, aircraft modification and modernisation. Aircraft Industries possesses unique know-how, a well-developed technological background and a highly qualified staff (OS KOVO 2016). With the acquisition, UGMK sought to diversify and branch out into new businesses, including regional air services and short-range aircraft (Finance.cz 2008). The company employs around a thousand people. Aircraft Industries also operates Kunovice's private international airport and an aviation high school (Aircraft Industries n.d.).

There is one other Russian-involved company in Czechia related to the nuclear sector. In 2011, TVEL, belonging to the Russian Rosatom Group, and the Czech engineering company Alta Invest formed a joint venture, Alvel, majority owned by Alta, with the aim of localising fuel services for Czech and European nuclear power plants and promoting TVEL fuel types

\footnotetext{
${ }^{7}$ Gazprom has not had control over Gazprombank for many years.
} 
designed for Western reactors (Nuclear Engineering International 2011). Rosatom's representative office responsible for the Central European region is based in Czechia (called Rosatom Central Europe), with a branch located in Hungary.

The next important Russian-owned company deals with software solutions and electronic production. Sistema's company in Czechia, NVision Czech Republic, formerly called Strom telecom, is the main research and development centre of Russia's NVision Group OSS/BSS (operations support systems, OSS; business support systems, BSS) division. Controlled by Vladimir Yevtushenkov, the Russian Sistema conglomerate is mainly interested in information technology, telecommunications and microelectronics in the EU. NVision Czech Republic is both a supplier of end-to-end systems and services to telecom operators and a manufacturer of computing and telecommunication equipment. The Czech company has for years been a prime asset of the NVision Group, while previously - of the Sitronics Group. Sitronics was established in 2002 as Kontsern Nauchnyy Tsentr (in English-Concern Scientific Centre), consisting of the Russian microelectronics producer NIIME \& Micron and Strom telecom (TASS 2011).

In the light industry, the Russian workwear manufacturer Vostok-Service has pursued successful international expansion through the Czech company Cerva Export Import, bought by Vostok-Service in 2006. Cerva was the first foreign asset of Vostok-Service, owned by former Russian parliamentarian Vladimir Golovnev. Vostok-Service chose Cerva because it was growing quite fast and Vostok-Service considered it to have potential for further development, as Cerva had been oriented toward a market interested in cheap products, with its main product being gloves. Vostok-Service believed that Cerva could tap into the market of better-quality products and expand its range of products (Pražský Telegraf 2013). Indeed, Cerva turned into an international holding company (Dmitriyeva 2017). It has bought several production assets abroad and either established 100 per cent subsidiaries and joint ventures or made acquisitions in sales, marketing and distribution abroad.

Two Russian banks - the First Czech-Russian Bank (FCRB) and Sberbank-have owned subsidiaries in Czechia. The Czech central bank granted an operating license to the FCRB subsidiary, ERB, in 2008. FCRB was founded in 1996 with majority shares by the now-defunct Czech Investment and Post Bank (IPB Bank) and was later controlled by Russian businessman Roman Popov. In 2009, ERB opened its headquarters in Prague. ERB aimed to break into the European trade-finance market. They considered themselves to have a good understanding of Russian risks, the Russian way of doing business and the mentality of Russian clients. Also, they did not see much Russian competition in Czechia (Global Trade Review 2009). However, Western sanctions and Russian counter-sanctions have seriously hit ERB Bank. The CBR revoked FCRB's licence in July 2016, and ERB Bank also lost its license in October 2016 (bne IntelliNews 2016). At that time, 22 per cent of the total 5400 clients were foreigners from 48 different countries, but mostly from Russia (EFDI 2017). ERB Bank was one of the smallest players on the Czech market. It only had branches in Prague and Karlovy Vary in Czechia (Blesk.cz 2016).

In 2012, Sberbank, Russia's largest lender controlled by the CBR, became the owner of Volksbank International AG (excluding the Romanian subsidiary). It bought operations in Slovakia, Czechia, Hungary, Slovenia, Croatia, Serbia, Bosnia and Herzegovina and also Ukraine. In Czechia, Sberbank has 28 branches with around 840 employees (Sberbank Europe n.d.). Although Russian clients were said to be important for Sberbank, it has made it clear since the beginning that they are not its sole focus in Czechia (Hovorka 2013).

Finally, Russians have established a palpable presence in the Czech real-estate industry. First of all, they have very significant capital investment in hotels and other real estate in the famous Karlovy Vary spa resort. 


\subsubsection{Hungary}

Statistics on Russian FDI in Hungary show only a few major transactions, including the unsuccessful takeover attempt of Mol by Surgutneftegaz, and a few changes connected to the Rakhimkulov family, namely Megdet Rakhimkulov and his two sons.

For almost 20 years after 1989, Russian corporate presence in Hungary was facilitated through the activities of Megdet Rakhimkulov. He established his fortune in the first half of the 1990s as a senior manager at Gazprom and as its Hungarian representative. In those years, Budapest was by far Gazprom's biggest export destination in the CEE region and the company's management attempted to maintain some of its revenues in Hungary. Not surprisingly, Gazprombank (at the time Gazprom's subsidiary) purchased a Hungarian bank, General Banking and Trust (ÁÉB), as early as in 1996, which was later gradually taken over by the Rakhimkulov family's companies. Rakhimkulov was involved in facilitating the purchase of stakes in two Hungarian (petro)chemical plants: TVK (now Mol Petrochemicals) and BorsodChem. ${ }^{8}$ Rakhimkulov was also associated with Surgutneftegaz's 2009 attempt at a hostile takeover of Mol. His influence reached its zenith in the mid-2000s. Over the next years, he gradually retired and formally moved back to Moscow. His two sons took over much of the family's business activities in Hungary and Cyprus. In the 2000s, the Rakhimkulov family rationalised its portfolio. All the chemical and machine-industry plants and even ÁÉB were sold in the mid-2000s. Today, the Rakhimkulov family primarily seems to play the role of financial investors. For a long time, Megdet Rakhimkulov and his two sons had held a combined stake of around 8.5 per cent in Hungary's leading retail bank, OTP Bank, considered a portfolio investment, constituting by far the biggest item on the list of Russian investments in Hungary (Deák and Weiner 2016). End-2019 data show that Kafijat, the well-known Hungarian company of the two Rakhimkulov brothers, has a 6.9 per cent stake in OTP (OTP Bank n.d.).

Gazprom's main ownership interest in Hungary is Panrusgáz, an intermediary joint venture for Russian gas imports via Hungary's major long-term gas supply contract. The original motivation behind Panrusgáz's complicated scheme was likely Gazprom's desire to keep the gas sale revenues abroad, outside Russia, as generally suggested above. Nonetheless, today, it does not pursue any practical activities except for transferring wholesale gas with relatively low margins.

Among the Hungarian gas traders, one has a Russian owner. WIEE Hungary is a subsidiary of the Swiss Gazprom Schweiz. Until recently, Centrex Hungary was also certainly in Russian hands, since its parent company, the Vienna-based Centrex Europe Energy \& Gas, was owned by Gazprombank. ${ }^{9}$ Further, there was a trader, an obscure one, called MET Hungary, which had some Russian interest.

Gazprom's other plans and projects in Hungary include failures. Investment in Hungary's oil industry has also involved many failed efforts, such as those of Yukos, Surgutneftegaz, Lukoil and Gazprom Neft. Yet, Gazprom Neft, Gazprom's oil arm and Russia's fourth-largest crude producer, is still active in Hungary via Serbia's NIS oil company, the majority of which is owned by Gazprom Neft.

Apart from Russia's presence in the energy sector, there are only a limited number of important assets under Russian ownership. In Hungary, there have only been two Russianowned banks, including, in the past, ÁÉB, and, now, a subsidiary of Sberbank. Besides these, Russian banks set up representative offices in Hungary, and in 2019 the International Investment Bank, a multilateral development bank, also moved its headquarters to Budapest from Moscow.

\footnotetext{
${ }^{8}$ Since 2003, Gazprom has not held any stakes in either company.

${ }^{9} \mathrm{We}$ do not have information on the final beneficiary of the 2019 transaction.
} 
According to Megdet Rakhimkulov, at the time when Gazprombank acquired ÁÉB, Gazprom identified Hungary as a strategic country and Mol as a strategic partner. Several largescale international projects between Russia and Hungary were agreed upon at the governmental level. Gazprom thus purchased ÁÉB. However, in the end, according to Rakhimkulov, Gazprom's new management changed its investment strategy for Hungary and the region, and ultimately lost interest in ÁÉB (Figyelő 2004). Gazprombank pulled out of ÁÉB in 2005. Following this decision, commercial banking business was not pursued for a number of years. ÁÉB was the eighth largest bank in Hungary (New Europe 2003). At the end of 2005, ÁÉB had a total of only 17 branches. Previously, about 70 per cent of ÁÉB's operations had been devoted to Gazprom and Gazprombank. In 2004, this proportion accounted for only about 8-10 per cent, but a large part of the operations were still linked to Russian clients (Simon and Szép 2005). ÁÉB branches were taken over by Hungarian Volksbank, which was a subsidiary of the Austrian Volksbank.

Traces of historical continuity can be observed in the fact that some of the Hungarian branches of Sberbank Hungary were previously owned by ÁÉB. Initially, the primary objective of Sberbank Hungary was to provide comprehensive services to Russian private and corporate clients, and to enhance trade between CEE countries and the CIS (Kalotay et al. 2014: 28-29). Sberbank currently operates only 27 branches in Hungary (Sberbank Hungary n.d.).

Additionally, there is a strong Russian presence in Hungarian metallurgy, and there have also been a few Russian capital-related projects in Hungary's machinery worth mentioning. One large industrial investment is the ISD Dunaferr steel plant in Dunaújváros situated some 70 kilometres south of Budapest. By the end of the 1990s, Hungarian metallurgy was struggling, due to their low scale of economy, lack of capital and inefficient management. For external producers, these capacities offered a means of bypassing EU protectionism of the steel market (Deák and Weiner 2016). In 2003, Dunaferr was tendered and privatised by a consortium, consisting of Ukraine's Industrial Union of Donbass (ISD) and the Swiss Duferco International Trading Holding. Severstal also submitted a bid. However, a change of ownership occurred in 2009, when Russian investors obtained a 50 per cent plus two stake in the metallurgical assets of ISD. Later, as a creditor, Russia's state-owned Vnesheconombank (VEB) practically controlled ISD, but in 2017, Hungarian media sources suggested that Dunaferr had a new Russian owner, Suleyman Kerimov, a Russian billionaire and representative of the Republic of Dagestan in the Federation Council of the Federal Assembly of Russia, though this has never been confirmed.

A further Russian-related company is VBH Budapest, established in 1992, a wholesaler and retailer of metal fittings. It is the Hungarian subsidiary of the German VBH Holding, a market leader in the fittings industry in Europe, majority-owned by the Russian businessman Viktor Trenev.

In the Hungarian machine-building industry, in light of the construction of new units at Hungary's Paks Nuclear Power Plant (Paks II) by the Russians, the most relevant company with Russian involvement is Ganz Engineering and Energetics Machinery, owned by TsKBM, a part of Rosatom's machine-building division Atomenergomash. Ganz Engineering and Energetics Machinery is involved in the manufacture and installation of hydromachines, nuclear power station machinery and oil drilling equipment.

Another Russian-Hungarian big business could be reached in the sector if, through the Russian-Hungarian TMH Hungary Invest, Transmashholding-Russia's largest railway machine-building company, majority owned by Iskander Makhmudov, Andrei Bokarev, Dmitry Komissarov and Kirill Lipa-acquires 50 per cent of the state-controlled Hungarian Dunakeszi Jarmüjavító where half of a 1300 passenger car order is to be manufactured for the Egyptian National Railways according to a 2018 contract between the Russian-Hungarian Transmashholding Hungary and the Egyptian National Railways. 
The activities of Uraltrak are also related to the machine industry. Established in 1990, it is the only official Hungarian dealer of Russia's Chelyabinsk Tractor Plant-Uraltrak, owned by the Russian state-owned tank and railway car manufacturer Uralvagonzavod. Chelyabinsk Tractor Plant is involved in the engineering and production of industrial tractors and engines.

Renova Group, whose beneficial owner is Viktor Vekselberg, a Russian tycoon, has been present in Hungary over the years with three Swiss high-tech and engineering groups (Oerlikon, Schmolz + Bickenbach and Sulzer), in which it now owns at most only minority stakes. Of the production sites of the Oerlikon Group, one is located in Hungary. Oerlikon Eldim (HU) produces honeycomb products used in aero engines. The second subsidiary, Schmolz + Bickenbach Magyarország, is a wholesaler of specialty steels deriving from the group's mills. In contrast, Sulzer's Hungarian subsidiary, Sulzer Pumps Wastewater Hungary, was sold in 2013. Under its new name, Zultzer Pumpen, the company continues its activities in the sales, service and operation of pumps, mixers, flow boosters, fans and blowers.

One more relatively widely known Russia-owned company is LIT Budapest, incorporated in 2006, dealing with disinfection technologies, including the use of UV in the treatment of drinking water, wastewater, technological water and water for swimming pools and spas. The company's main activities encompass the sale and installation of equipment, maintenance and servicing. Russia's LIT is reportedly among the world's top three developers and manufacturers of UV systems for water, air and surface disinfection.

The activities of Russian investors in the Hungarian logistics and transportation industry have been paved with failures. An exception is GEFCO Hungary, a subsidiary of the French GEFCO, 75 per cent owned by Russian Railways RZD. GEFCO Hungary was established in 2006. With its headquarters in Budapest, its logistics base is located in Biatorbágy, a village near the capital. In 2019, the number of employees rose to reach over 90 (GEFCO n.d.). GEFCO offers a wide range of logistics services and transport solutions by road, sea, air and rail.

The presence of Russian residents in Hungary's real-estate market is a visible phenomenon. Budapest and Zala County in the country's westernmost region (with special focus on the spa city of Hévíz) are the most attractive destinations for Russian residential real-estate owners. In contrast, the 232-room Lotus Therme Hotel \& Spa, the only five-star hotel in Hévíz, can serve as an example of the presence of Russians in the Hungarian hotel and spa industry. Hungary is interesting for Russian tourists primarily because of medical tourism.

Russian FDI in Hungary could have been much larger than it is at present, but - similarly as in the case of Poland-Russian investors have been involved in a couple of unsuccessful takeover attempts in Hungary, which failed due to local resistance to Russian capital.

\subsubsection{Slovakia}

In Slovakia, Russia has quite moderate FDI activities and involves more stories of failure than success. However, the share of FDI from countries with lax transparency standards for ownership structures (Cyprus, Lichtenstein and Luxemburg) and, therefore, the possible involvement of Russian capital remain relatively high in Slovakia (Takáč 2019: 222).

In the gas sector, Gazprom is active only through Vemex Energo, founded in Czechia in 2003 to trade in gas and electricity. The Gazprom joint venture Slovrusgas, a middleman gas trader, went into liquidation in 2005 and was dissolved in 2010. Slovrusgas was established during the last months of Vladimir Meciar's premiership in 1998 (Nosko 2013: 147-148). It received the right to import gas above the volume agreed upon in the Russian long-term gas supply contract. It was also agreed that Gazprom would spend up to 40 per cent of its gas sales revenues on buying Slovakian goods and services and selling them on the Russian market. However, this deal proved to be problematic (Orbán 2008: 51, 57). Nonetheless, Gazprom could 
have played a role in Slovakian gas transit, but in 2005 it decided not to exercise the option to buy a 16.3 per cent stake in the Slovak Slovensky Plynarensky Priemysel (SPP), due to the unclear benefits of the deal and plans to develop the North European gas pipeline (later called Nord Stream). In the mid-2000s, SPP, an integrated gas company (excluding exploration and production), covering gas storage, transmission, distribution and trade, launched an extensive restructuring (unbundling) operation in accordance with EU requirements (Weiner 2006: 20).

In the oil sector, although Yukos took over a 49 per cent stake in Slovakia's oil transporter Transpetrol during the privatisation process conducted in 2002, the Slovakian state bought it back in 2009. In 2001, Yukos emphasised that increasing oil production and securing sales for Russian and Kazakh oil were Yukos' main motives for interest in Transpetrol. Yukos stated that extensive technical measures had to be taken to utilise Transpetrol's unused capacities and a strong oil producer was the guarantee for such an investment. Furthermore, Yukos believed that Transpetrol, which was at the heart of the regional oil pipeline system, would make it possible to work with neighbouring oil pipelines and open new oil transport opportunities, above all, reversing the flow of the Adria oil pipeline between Hungary and Croatia to gain access to the Croatian oil terminal Omišail and from there to the Balkans and, for example, to the United States. In addition, Yukos thought that by accessing Transpetrol it could improve its position in negotiations with Czechia and Germany on oil deliveries to Germany (Špáni 2001). Another failure relates to Lukoil, which, as mentioned, sold its Slovakian filling stations.

Sberbank's activities were also discontinued in Slovakia. In August 2017, its subsidiary Sberbank Slovensko was merged into Prima banka Slovensko. Sberbank had 39 offices in Slovakia.

In contrast, Slovakia has performed an important role in the activities of UTair, Russia's No. 1 helicopter operator and world leader in the helicopter market in terms of fleet size and carrying capacity. UTair has been represented in Slovakia by its subsidiary UTair Europe since 2006. UTair's main base in Europe is the international airport at the spa town of Piešt'any in Slovakia. UTair Europe's helicopters are used for aerial work mostly in inaccessible terrain.

Finally, as indicated, Skoda JS of Czechia runs a branch in Slovakia. Until recently, it also owned a separate subsidiary Skoda Slovakia, but this merged into Skoda JS in 2019. Skoda Slovakia was founded in 1995. Skoda Slovakia and thus the new Slovakia Division deal with the construction, maintenance, repair, modernisation and decommissioning of facilities in nuclear energetics and of hydropower plants and in classical energetics, chemical, petrochemical and heavy industry, as well as trading and transport.

\subsubsection{Slovenia}

Finally, Slovenia has also attracted some Russian FDI. The first serious Russian FDI investor in Slovenia was the Kemerovo coking coal plant, known as Koks, one of Russia's leading producers and exporters of merchant metallurgical coke. Koks is part of the Industrial Metallurgical Holding, owned by the family of the late Boris Zubitsky, a former State Duma deputy. In 2007, through privatisation, Koks bought the majority of the SIJ Group, the largest Slovenian vertically integrated metallurgical group. SIJ was one of the few non-global steel companies in the EU. As a raw material supplier, it was Koks' goal to enter the market of finished products, used by the Slovenian industry (Lesjak Tušek 2007). On the other hand, vertical integration was crucial for the development of SIJ, as it is very sensitive to fluctuations in raw material and energy prices (SPIRIT Slovenia 2007). It was contended that Koks and the SIJ Group were complementary and not in competition (Warga 2007). Among the synergy effects, the possibility of increasing sales in Russia was mentioned, as SIJ's focus was on Western markets (Lesjak Tušek 2007). In 2012, Koks explained that making steel in Russia 
would be too expensive, and producers in Russia also lacked the know-how necessary for the production of special kinds of steel (SPIRIT Slovenia 2012).

In Slovenia, Sberbank operates a network of only 12 branch offices. The Slovenian Sberbank unit achieved portfolio growth when in 2014 it took over the retail loan portfolio of Slovenia's Probanka during the latter's controlled liquidation (Ljubljanska borza 2014).

In addition, Russia has some interest in Slovenian tourism. In 2012, Platanus, a Slovenian firm then reportedly owned by a Russian citizen and incorporated in 2010, bought a majority stake in the Maribor-based tourism company Terme Maribor, at that time owner of hotels, travel shops and a medical centre (The Slovenia Times 2012). Since 2014, Platanus has been controlled by the Gazprom Group.

Slovenia is one of Gazprom's smallest gas markets, but it could have received significant amounts of Russian FDI and gained an important transit role if the South Stream gas pipeline, aimed at running under the Black Sea to Bulgaria and then onwards, had been built. Thus, in 2012, the Slovenian-Russian joint project company Južni tok Slovenija was established to supervise the Slovenian South Stream section. Other plans were also considered relating to the South Stream project. However, in 2012, Gazprom Telecom, offering telecommunication and internet connectivity services and operating as a subsidiary of Gazprom, and Slovenia's Comita, developing technologies in the energy and telecommunications sectors, created the South Stream Telecom joint venture in Switzerland for the operation and provision of integrated telecommunications services at main communication lines along the entire South Stream gas pipeline (Gazprom 2012). In 2014, plans between Comita and Gazprom were further developed with the possibility of setting up a joint venture aimed at comprehensively developing the natural gas vehicle (NGV) sector in the South Stream project countries (Gazprom 2014). After abandoning South Stream, Comita said in 2015 that they were examining the option of implementing the joint South Stream Telecom project with Gazprom within the TurkStream framework, a project substituting South Stream, and runs from Russia to Turkey across the Black Sea (TASS 2015).

In 2009, media suggested that Gazprom might be interested in acquiring Slovenia's largest fuel retailer Petrol, but this was never carried out. In the early 2010s, plans to cooperate in terms of the supply and distribution of oil products in Southern Europe and the Balkan states were also disseminated. For this purpose, Gazprom Neft and Petrol signed a memorandum of understanding in 2011 (Gazprom Neft 2011).

\subsection{Summary and Conclusions}

Investigating the Russian economic footprint through OFDI and the activities of Russian multinationals has not become either outdated or less interesting, even though most of the current attention on Russian influence in Europe has been focused on direct interference in political affairs.

Russia has a long history of OFDI, with the golden era ending with the global financial meltdown. By that time, Russian multinationals had become significant factors in international capital flows, though they have never been ranked among the largest multinationals. Having faced two financial crises over the past 12 years that interrupted the upward trend, the current period is about their withdrawal or survival.

Among the important features of Russian OFDI, the most well-known ones are roundtripping and trans-shipping that allow Cyprus to lead the list of Russian FDI recipients. Roundtripping leads to Russian FDI being overestimated in both directions. Round-tripping and the offshore orientation of Russian OFDI are strongly related to the tax minimisation strategies of Russian multinationals and to negative domestic push factors. Domestic push factors are very 
important in driving corporate decisions to invest abroad. Concerning a typical positive push factor, the Russian state's role in directly promoting foreign expansion, one can argue that the state supports only the largest Russian multinationals but Russian OFDI is not dominated by state-controlled companies. State-owned companies possess many advantages that can help them internationalise. However, the Russian state's influence on private companies is also frequently quite significant.

Due to the specific features of Russian OFDI and the lack of statistics referring to the ultimate host/investing country, the role of certain host countries is underestimated, while that of others is overstated. Nevertheless, Europe's leading role in Russian OFDI remains unchallenged, though Europe's share has been falling. This began many years ago and was not directly linked to EU-Russia relations, which - in turn - have definitely reached a very low point at present. Russia's pivot towards Asia as a means of diversifying away from Europe had been formulated before the events in Ukraine. Nonetheless, despite some steps in this direction, a dramatic increase in Russian expansion has not been witnessed and is not projected.

In Europe, possibly Italy, Germany and the United Kingdom are the largest recipients of Russian FDI. In CEE, Bulgaria, Serbia and Romania can be mentioned. ECE countries are not among the main destinations, though Russian FDI in Czechia or Poland is also not negligible. Even Slovenia has received notable Russian-involved companies. Nevertheless, company data demonstrate that the activities of Russian investors in ECE countries have been paved with failures. These have been evident in both divestments and unrealised plans. The low share of Russian investment in ECE countries may be referred to as business opportunities that the Russian parties have failed to exploit.

Generally speaking, Russian investment in ECE countries is dominated by market-seeking and, to a lesser extent, efficiency-seeking projects carried out by state-owned or state-related private firms. Most Russian FDI has been done in hydrocarbons, iron, steel and machinery, but banking, software solutions, electronic production, real estate and even the light industry have also been targeted.

As extant theories of international investment - with the exception of Dunning's eclectic paradigm - have limited explanatory power concerning the activities of Russian multinationals in ECE countries, and can hardly even explain the existence of such firms, we - following Kalotay et al. (2014) — analysed the ownership advantages of Russian investors primarily by using the eclectic paradigm, duly adapted to the specifics of the discussed group of companies.

Contrary to findings in the literature on other emerging multinationals (Mathews 2002; Narula 2006), we found only traces of acquiring competitive advantages or ownership advantages. Rather, we identified investment aiming at exploiting existing advantages. This may be due to the fact that there is a very small number of this type of acquisition targets in ECE countries. As for Russian firms' asset-based advantages, it is obvious that their access to domestic raw materials and related technical knowledge is very important for their investments in ECE countries, as investments in oil, gas and metals are predominant. Another industry performing similarly is nuclear energy production. The asset-based advantages of Russian firms in ECE countries are closely related to their transaction-based advantages. The most evident case is that of the financial services sector. Both the asset and transactional ownership advantages of Russian firms are reinforced by the location advantages of ECE countries as these countries heavily rely on certain Russian natural resources, though to different extents. Similarly to hydrocarbons, iron and steel, as well as nuclear energy industries, the machinery industry also shows an interconnection of ownership and location advantages. For technologybased companies, the location advantages are not specific to ECE countries in the case of market-seeking motivations; but such factors are involved when it comes to efficiency-seeking motivations. Investigating the motives for and patterns of Russian investment in ECE countries, we can state that the technology-based firms show characteristics similar to developed-country 
multinationals. Other large state-owned and natural-resource-based firms are not similar to traditional multinationals. Yet others, for example real-estate investors, fall under no straightforward categorisation. A location disadvantage is also at play. Several examples of negative approaches towards Russian capital in ECE countries could be found, though the reactions of the host governments to Russian multinationals have been mixed (see Kalotay et al. 2014).

We suggest that the main elements of the OLI paradigm could be applied when explaining Russian FDI in these countries, but its extension with home-country factors seems to be necessary. This refers first of all to natural-resource-based multinationals, mainly oil, gas and steel, but home-country interest is also prevalent in other industries. In the case of Russian multinationals active in innovative industries, home-country factors play a minor role (see also Kalotay et al. 2014).

Opposition to Russian investment could continue to grow in the EU. While examples of Russian pressure on companies to sell to them have been known to occur in CEE countries within the EU, there are also already precedents in Western EU states for transactions that have failed because of resistance to Russian investment. In general, there is no need to worry about Russian OFDI, but some of the expressed concerns have certainly been attested. We believe that it is the Russian party who would benefit most from alleviating these fears.

\section{References}

Aircraft Industries. (n.d.). Company Profile. Retrieved from http://www.let.cz/documents/companyprofile.pdf. Anwar, A., \& Mughal, M. Y. (2014). Why do Russian Firms Invest Abroad? A Firm Level Analysis. MPRA Paper, No. 58178. Munich Personal RePEc Archive. Retrieved from https://mpra.ub.unimuenchen.de/58178/1/MPRA_paper_58178.pdf.

Belton, C. (2008). Copy China and Invest Abroad, Says Medvedev. Financial Times, 31 January. Retrieved from https://www.ft.com/content/850ccda0-d02e-11dc-9309-0000779fd2ac.

Blesk.cz. (2016). Vklady klientů ERB bank budou vyplácet od čtvrtka pobočky ČS. 17 October. Retrieved from http://www.blesk.cz/clanek/zpravy-live-ekonomika/424993/vklady-klientu-erb-bank-budou-vyplacet-odctvrtka-pobocky-cs.html.

bne IntelliNews. (2016). Czech National Bank Shutters Russian Exports Lender ERB. 24 October. Retrieved from http://www.intellinews.com/czech-national-bank-shutters-russian-exports-lender-erb-108735/.

Bulatov, A. (2017). Offshore Orientation of Russian Federation FDI. Transnational Corporations, 24(2), 71-89.

Bulatov, A., Kuznetsov, A., Kvashnin, Y., Maltseva, A., \& Seniuk, N. (2016). Russian MNCs: Empirical and Theoretical Aspects. In R. van Tulder, A. Verbeke, J. Carneiro, \& M. A. Gonzalez-Perez (Eds.), The Challenge of BRIC Multinationals (Progress in International Business Research, 11) (pp. 395-421). Emerald Group Publishing Limited.

CBR. (2019a). Direct Investment in the Russian Federation: Inward Positions by Instrument and Partner Country (Directional Principle). Retrieved from http://www.cbr.ru/vfs/eng/statistics/credit_statistics/direct investment/10e-dir_inv.xlsx.

CBR. (2019b). Direct Investment in the Russian Federation: Positions by Instrument and Partner Country (Asset/Liability Principle). Retrieved from http://www.cbr.ru/vfs/eng/statistics/credit_statistics/direct investment/dir-inv_in_country_1_e.xlsx.

CBR. (2019c). Direct Investment of the Russian Federation Abroad: Outward Positions by Instrument and Partner Country (Directional Principle). Retrieved from http://www.cbr.ru/vfs/eng/statistics/credit_statistics/direct_investment/16e-dir_inv.xlsx.

CBR. (2019d). Direct Investment of the Russian Federation Abroad: Positions by Instrument and Partner Country (Asset/Liability Principle). Retrieved from http://www.cbr.ru/vfs/eng/statistics/credit_statistics/direct_investment/15e-dir_inv.xlsx.

CBR. (2020a). Direct Investment of the Russian Federation by Institutional Sector. Retrieved from http://www.cbr.ru/vfs/eng/statistics/credit_statistics/direct_investment/21e-dir_inv.xlsx.

CBR. (2020b). Direct Investment of the Russian Federation by Instrument (Directional Principle). Retrieved from http://www.cbr.ru/vfs/eng/statistics/credit_statistics/direct_investment/22e-dir_inv.xlsx. 
Deák, A. (2017). Emerging Diversity in Russia's Energy Relations: What Role for Europe? The First Ghent Russia Colloquium, 'EU-Russia Relations: How to Get Out of the 'Midlife' Crisis?" Ghent: Ghent University, 22 September.

Deák, A., \& Weiner, C. (2016). Country Report: Hungary. Unpublished manuscript prepared for the project "Russian Economic Influence in New Europe", Center for the Study of Democracy (Sofia) and Center for Strategic and International Studies (Washington, DC).

Deloitte. (2008). Russian Multinationals: New Players in the Global Economy. Moscow: Deloitte CIS.

Dmitriyeva, A. (2017). Petr Khorak: Serva Group -25 let na rynke. Bolshaya yevropeyskaya mechta. Getsiz.ru, 22 May. Retrieved from http://getsiz.ru/bolshaya-evropeyskaya-mechta-serva-group-25-let-na.html.

E15.cz. (2014). Lukoil odchází z Česka, benzinky prodá mad’arské Mol. 4 August. Retrieved from https://www.e15.cz/byznys/prumysl-a-energetika/lukoil-odchazi-z-ceska-benzinky-proda-madarske-mol1107239.

EABR. (2017). YeAES i strany Yevraziyskogo kontinenta: monitoring i analiz pryamykh investitsiy. Doklad, No. 47. Saint-Petersburg: Tsentr integratsionnykh issledovaniy Yevraziyskogo banka razvitiya.

EFDI. (2017). EFDI PR Committee Meeting: Changes ante portas... (27 Feb, Prague, Czech Republic). Newsletter, No. 7: 7. Retrieved from http://www.efdi.eu/sites/default/files/publications/2017_efdi_newsletter_no_7.pdf.

Ekoton. (n.d.-a). About Company. Retrieved from https://ekoton.com/about.

Ekoton. (n.d.-b). O nas. Retrieved from http://www.ekoton.pl/FIRMA/o-nas.

Eurostat. (2019). EU Direct Investment Positions, Breakdown by Country and Economic Activity (BPM6) [bop_fdi6_pos]. Last update June 17, 2019. Retrieved from http://appsso.eurostat.ec.europa.eu/nui/show.do?dataset=bop_fdi6_pos\&lang=en.

Evraz. (2005). Evraz Group S.A. Completes Acquisition of Vitkovice Steel. News, 15 November. Retrieved from https://old.evraz.com/media/news/1711/.

Figyelő. (2004). Rahimkulov a Gazprom-szálról. 4 November. Retrieved from https://24.hu/belfold/2004/11/04/rahimkulov_gazprom_szalrol/.

Filippov, S. (2008). Russia's Emerging Multinationals: Trends and Issues. UNU-MERIT Working Paper Series, No. 62. Maastricht: United Nations University, Maastricht Economic and Social Research and Training Centre on Innovation and Technology. Retrieved from http://www.merit.unu.edu/publications/wppdf/2008/wp2008-062.pdf.

Finance.cz. (2008). Russian Miner UMMC Buys 51 pct of Czech Plane Maker. 2 June. Retrieved from https://www.finance.cz/zpravy/reuters/MTFH41497nL02531220-russian-miner-ummc-buys-51-pct-of-czechplane-maker/.

Fortescue, S., \& Hanson, P. (2015). What Drives Russian Outward Foreign Direct Investment? Some Observations on the Steel Industry. Post-Communist Economies, 27(3), 283-305.

Gazeta Wrocławska. (2015). Luxoft Poland otworzył swoje drugie centrum IT we Wrocławiu. 16 March. Retrieved from http://www.gazetawroclawska.pl/strefa-biznesu/firma/a/luxoft-poland-otworzyl-swojedrugie-centrum-it-we-wroclawiu,10153778/.

Gazeta Wyborcza. (2016). Luxoft-juě 2000 pracowników w Polsce, zatrudni jeszcze kilkaset. 15 April. Retrieved from http://krakow.wyborcza.pl/krakow/1,44425,19926779,luxoft-juz-2000-pracownikow-wpolsce-zatrudni-jeszcze-kilkaset.html?disableRedirects=true.

Gazprom. (2012). Gazprom and Comita Discuss Work Plans for South Stream Telecom AG JV. Release, 26 December. Retrieved from http://www.gazprom.com/press/news/2012/december/article152915/.

Gazprom. (2014). Gazprom and Comita May Set up NGV Joint Venture in South Stream Project Countries. Release, 23 May. Retrieved from http://www.gazprom.com/press/news/2014/may/article191729/.

Gazprom Germania. (2015). 2014 Group Annual Report. Retrieved from https://www.gazpromgermania.de/fileadmin/templates/pdf/Geschaeftsberichte_2014/GPG_IFRS_2014_E_web.pdf.

Gazprom Neft. (2011). Gazprom Neft and Slovenian Petrol Sign Memorandum of Understanding. Press Release, 22 March. Retrieved from https://www.gazprom-neft.com/press-center/news/3912/.

GEFCO. (n.d.). GEFCO Magyarország. Retrieved from https://hu.gefco.net/hu/orszag/gefco-magyarorszag.

Gera, V. (2013). Poland Emerging as Major European Outsourcing Hub. U.S. News, 27 February. Retrieved from https://www.usnews.com/news/world/articles/2013/02/27/poland-emerging-as-major-europeanoutsourcing-hub.

Global Trade Review. (2009). New Russian Bank Secures First for Europe. 7 May. Retrieved from https://www.gtreview.com/news/europe/new-russian-bank-secures-first-for-europe/.

Helmer, J. (2014). Evraz Plays the Hidden Hand: Vitkovice Steel Sale is a Related-Party Transaction. johnhelmer.net, 17 April. Retrieved from http://johnhelmer.net/evraz-plays-the-hidden-hand-vitkovice-steelsale-is-a-related-party-transaction-in-which-sergei-taruta-acting-donetsk-governor-gets-a-reward-he-cantafford/. 
Hovorka, J. (2013). Russian bank giant Sberbank aims high in Czech Republic. Aktuálně.cz, 1 March. Retrieved from https://zpravy.aktualne.cz/russian-bank-giant-sberbank-aims-high-in-czechrepublic/r i:article: $772811 /$ ?redirected $=1503136678$.

IMEMO. (2009). Russian Multinationals Continue Their Outward Expansion in Spite of the Global Crisis. EMGP Report, 2 December. Moscow/New York: IMEMO and Vale Columbia Center on Sustainable International Investment. Retrieved from http://ccsi.columbia.edu/files/2013/10/Russia_2009.pdf.

IMEMO. (2011). Investment from Russia Stabilizes After the Global Crisis. EMGP Report, 23 June. Moscow/New York: IMEMO and Vale Columbia Center on Sustainable International Investment. Retrieved from http://ccsi.columbia.edu/files/2013/10/Russia_2011.pdf.

Kalotay, K. (2003). Outward Foreign Direct Investment from Economies in Transition in a Global Context. Journal for European Management Studies, 8(1), 6-24.

Kalotay, K. (2008). Russian Transnationals and International Investment Paradigms. Research in International Business and Finance, 22(2), 85-107.

Kalotay, K. (2010a). Takeoff and Turbulence in the Foreign Expansion of Russian Multinationals. In K. P. Sauvant, W. A. Maschek, \& G. A. McAllister (Eds.), Foreign Direct Investments from Emerging Markets: The Challenges Ahead (pp. 113-145). New York: Palgrave Macmillan.

Kalotay, K. (2010b). The Future of Russian Outward Foreign Direct Investment and the Eclectic Paradigm: What Changes After the Crisis of 2008-2009? Competitio, 9(1), 31-54.

Kalotay, K. (2015). Acquisitions as Engines of Foreign Expansion of Russian Multinationals. In M. Demirbag \& A. Yaprak (Eds.), Handbook of Emerging Market Multinational Corporations (pp. 239-259). Cheltenham/Northampton: Edward Elgar.

Kalotay, K., \& Sulstarova, A. (2010). Modelling Russian Outward FDI. Journal of International Management, 16(2), 131-142.

Kalotay, K., Éltető, A., Sass, M., \& Weiner, C. (2014). Russian Capital in the Visegrád Countries. Working Papers, No. 210. Budapest: Institute of World Economics, Centre for Economic and Regional Studies, Hungarian Academy of Sciences. Retrieved from http://real.mtak.hu/19519/.

Kaspersky. (n.d.). O nas. Retrieved from https://www.kaspersky.pl/o-nas.

Krainová, P. (2005). Akcie Vítkovice Steel byly převedeny. Ministerstvo financí České republiky, 14 November. Retrieved from https://www.mfcr.cz/cs/archiv/transformacni-instituce/agenda-byvaleho-fnm/archivkomunikace-fnm/2005/akcie-vitkovice-steel-byly-prevedeny-15445.

Kuznetsov, A. (2010a). Industrial and Geographical Diversification of Russian Foreign Direct Investments. Electronic Publications of Pan-European Institute, No. 7/2010.

Kuznetsov, A. (2010b). Masshtaby rossiyskoy investitsionnoy ekspansii v Yevrope. In A. Kuznetsov (Ed.), Vliyaniye rossiyskoy investitsionnoy ekspansii na obraz Rossii v Yevrope (pp. 19-28). Moscow: IMEMO RAN.

Kuznetsov, A. (2011). Evolyutsiya rossiyskikh TNK: ot regionalnykh kompaniy k globalnym. Vestnik federalnogo gosudarstvennogo uchrezhdeniya "Gosudarstvennaya registratsionnaya palata pri Ministerstve yustitsii Rossiyskoy Federatsii”, No. 4: 4-14.

Kuznetsov, A. (2013). Global Expansion of Russian Multinationals after the Crisis: Results of 2011. EMGP Report, 16 April. Moscow/New York: IMEMO and Vale Columbia Center on Sustainable International Investment. Retrieved from http://ccsi.columbia.edu/files/2015/04/Russia_2013.pdf.

Kuznetsov, A. (2014). Russian Multinationals FDI Outflows Geography: The Emerging Dominance of Greater Europe. European Research, 67(1-2), 130-135.

Kuznetsov, A. (2017). Prospects of Diversifying Russian Direct Investment Abroad. Studies on Russian Economic Development, 28(1), 79-86.

Lesjak Tušek, P. (2007). Ruski Koks in SIJ združila interese. Vseslovensko Združenje Malih Delničarjev, 3 March. Retrieved from http://www.vzmd.si/novice/mediji-o-vzmd/ruski-koks-in-sij-zdruzila-interese.

Liuhto, K. (2015). Motivations of Russian Firms to Invest Abroad: How do Sanctions Affect Russia’s Outward Foreign Direct Investment? Baltic Region, 7(4), 7-26.

Liuhto, K. (2016). Does Ownership Matter in an OFDI Decision of a Russian Firm? The Case of Russia's Ten Largest Investors Abroad. In K. Liuhto, S. Sutyrin, \& J.-M. F. Blanchard (Eds.), The Russian Economy and Foreign Direct Investment (pp. 248-265). Abingdon/New York: Routledge.

Liuhto, K., \& Majuri, S. (2014). Outward Foreign Direct Investment from Russia: A Literature Review. Journal of East-West Business, 20(4), 198-224.

Ljubljanska borza. (2014). Probanka, d. d., Maribor. Information on successful sale of assets. Public Announcements, 24 July. Retrieved from http://seonet.ljse.si/default en.aspx?doc id=55244\&language=en.

Luxoft. (2016). Luxoft invests in Warsaw adding new IT jobs in Poland. Press, 30 May. Retrieved from https://www.luxoft.com/pr/luxoft-invests-in-warsaw-adding-new-it-jobs-in-poland/.

Luxoft. (n.d.). Luxoft Corporate Profile. Retrieved from https://emn.gov.pl/download/75/18651/Luxoft.pdf. 
Mathews, J. A. (2002). Dragon Multinational: A New Model of Global Growth. Oxford: Oxford University Press.

MetalTorg.ru. (2006). Gruppa ChTPZ priobrela kontrol nad 100\% aktsiy cheshskogo zavoda MSA a.s. 6 June. Retrieved from https://www.metaltorg.ru/analytics/publication.php?id=2373.

Narula, R. (2006). Globalization, New Ecologies, New Zoologies, and the Purported Death of the Eclectic Paradigm. Asia Pacific Journal of Management, 23(2), 143-151.

Nestmann, T., \& Orlova, D. (2008). Russia’s Outward Investment. Deutsche Bank Research, 30 April.

New Europe. (2003). AEB Bank Expanding Horizons. 13 July. Retrieved from http://www.neurope.eu/article/aeb-bank-expanding-horizons.

New Europe. (2004). Skoda Holding Dumps 3 Units. 2 May. Retrieved from https://www.neweurope.eu/article/skoda-holding-dumps-3-units/.

New Europe. (2006). Arkley Capital acquires Czech's MSA. 11 June. Retrieved from https://www.neweurope.eu/article/arkley-capital-acquires-czech\%E2\%80\%99s-msa/.

Nosko, A. (2013). Energy Security in Transition: Coping with Energy Import Dependence in the Czech Republic, Slovakia and Hungary. Ph.D. Dissertation. Budapest: Central European University. Retrieved from http://www.etd.ceu.hu/2013/nosko_andrej.pdf.

Nuclear Engineering International. (2011). Through New Czech JV, TVEL Creeps up to Europe. 26 December. Retrieved from http://www.neimagazine.com/news/newsthrough-new-czech-jv-tvel-creeps-up-to-europe.

Orbán, A. (2008). Power, Energy, and the New Russian Imperialism. Westport, CT/London: Praeger Security International.

OS KOVO. (2016). Kunovice: Ministr Mládek chce jednat s majiteli Aircraft Industries. Retrieved from http://www.oskovo.cz/aktuality/kunovice-ministr-mladek-chce-jednat-s-majiteli-aircraft-industries.

OTP Bank. (n.d.). Tulajdonosi struktúra. Retrieved from https://www.otpbank.hu/portal/hu/IR Tulajdonosi_struktura.

Panibratov, A. (2013). The Influence of the State on Expanding Russian MNEs: Advantage or Handicap? Russie.NEI.Visions, No. 73. Paris: Ifri. Retrieved from http://www.ifri.org/sites/default/files/atoms/files/ifriandreypanibratovrussiancompagniesengdecember2013.p df.

Panibratov, A. (2017). International Strategy of Emerging Market Firms: Absorbing Global Knowledge and Building Competitive Advantage. Abingdon/New York: Routledge.

Panibratov, A., \& Kalotay, K. (2009). Russian Outward FDI and Its Policy Context. Columbia FDI Profiles, 13 October. New York: Vale Columbia Center on Sustainable International Investment. Retrieved from http://ccsi.columbia.edu/files/2014/03/FDI_Profile-_Russia.pdf.

Panibratov, A., \& Michailova, S. (2019). The Role of State Ownership and Home Government Political Support in Russian Multinationals' Internationalization. International Journal of Emerging Markets, 14(3), 436-450.

petrolnet.pl. (2016). Lukoil niespiesznie opuszcza Polskę. 20 September. Retrieved from http://www.petrolnet.pl/Lukoil-niespiesznie-opuszcza-Polske/.

Pilsen Steel. (2010). The Holding Group "United Group” Expects Threefold Increase in Sales Volume. Press Releases, 2 November. Retrieved from http://www.pilsensteel.cz/?mt=\&m=700\&id=253\&lang=1.

Power Machines. (2004). OMZ - Power Machines Group purchased Skoda Holding Subsidiaries. News, 23 April. Retrieved from http://www.power-m.ru/en/press-center/news/omz-power-machines-group-purchasedskoda-holding-subsidiaries/.

Pražský Telegraf. (2013). Červa Export Import: brend Chekhii v Yevrope. 7 November. Retrieved from http://ptel.cz/2013/11/cerva-export-import-brend-chexii-v-evrope/.

Prusińska, O. (2010). Białystok. Ekoton pracuje z Aton-Ht nad polską propozycją do Ekonobla. Poranny.pl, 21 July. Retrieved from http://www.poranny.pl/strefa-biznesu/wiadomosci/z-regionu/a/bialystok-ekotonpracuje-z-atonht-nad-polska-propozycja-do-ekonobla,10277994/.

Puls Biznesu. (2008). Severstallat zainwestuje w Sosnowcu blisko 20 mln euro. 21 May. Retrieved from https://www.pb.pl/severstallat-zainwestuje-w-sosnowcu-blisko-20-mln-euro-429260.

Rosstat. (2009). Investitsii v Rossii 2009. Moscow: Rosstat.

Rosstat. (2014). Finansy Rossii 2014. Moscow: Rosstat.

Roust. (2013). Russian Standard Acquires CEDC. News, 5 June. Retrieved from http://roust.com/news/russianstandard-becomes-2nd-largest-vodka-producer-in-the-world-with-acquisition-of-central-europeandistribution-corporation-.

Sberbank Europe. (n.d.). Czech Republic. Retrieved from https://www.sberbank.at/sberbank-europeag/sberbank-cee/czech-republic.

Sberbank Hungary. (n.d.). About Us. Retrieved from https://www.sberbank.hu/en/headline/about.html. 
Severstal. (2008). AO «Severstallat» v rezultate pismennykh ofertnykh torgov priobrelo imushchestvo predpriyatiya «Technologie Buczek S.A.», nakhodivshegosya v sostoyanii bankrotstva,—-soobshchil Predsedatel Soveta AO «Severstallat», chlen soveta direktorov OAO «Severstal» Anatoliy Kruchinin. Novosti, 26 March. Retrieved from https://www.severstal.com/rus/media/news/document3204.phtml.

Simon, E., \& Szép, I. (2005). Meg kell őszülni a sikerhez. Beszélgetés Medget Rahimkulovval, az Általános Értékforgalmi bank többségi tulajdonosával. Figyelö, 48(45), 68-71.

Skolkovo. (2007). Russian Multinationals Bullish on Foreign Markets. Moscow/New York: SkolkovoColumbia Program on International Investment, 10 December. Retrieved from http://www.skolkovo.ru/images/stories/book/SKOLKOVO_PRESSRELEASE_071210_TOP_25_RANKINGS_Eng.pdf.

Skolkovo. (2008). Emerging Russian Multinationals: Achievements and Challenges. Moscow/New York: Skolkovo and Columbia Program on International Investment, November. http://www.skolkovo.ru/images/stories/book/SKOLKOVO_Research_Emerging_Russian_Multinationals_En g.pdf.

Skolkovo. (2009). Global Expansion of Emerging Multinationals: Post-Crisis Adjustment. SIEMS Monthly Briefing, May. Skolkovo Institute for Emerging Market Studies. Retrieved from http://www.skolkovo.ru/images/stories/book/SIEMS_Monthly_Briefing_2009-05_eng.pdf.

Špáni, I. (2001). Yukos chce Transpetrol lepšie využit'. Hospodárske noviny, 13 December. Retrieved from https://dennik.hnonline.sk/podniky-a-trhy/44400-yukos-chce-transpetrol-lepsie-vyuzit.

SPIRIT Slovenia. (2007). Majority Stake in Steel Group Sold to Russian Company Koks. 5 March. Retrieved from https://www.sloveniapartner.eu/hot-topics/slovenia-business-week-no-09-majority-stake-in-steel-groupsold-to-russian-company-koks-7377.

SPIRIT Slovenia. (2012). Steel Group Owners Happy with Business in Slovenia. 28 December. Retrieved from https://www.investslovenia.org/news-and-media/business-news/steel-group-owners-happy-with-business-inslovenia-3929.

Takáč, K. (2019). Slovakia: Energy Dependence Vulnerabilities. In O. Shentov, R. Stefanov, \& M. Vladimirov (Eds.), The Russian Economic Grip on Central and Eastern Europe (Routledge Contemporary Russia and Eastern Europe Series) (pp. 221-231). Abingdon/New York: Routledge.

TASS. (2011). Russia's Sitronics Enters 100 Top World High-Tech Companies. 1 November. Retrieved from http://tass.com/archive/663559.

TASS. (2015). Slovenian Comita May Implement JV South Stream Telecom within Turkish Stream Project. 1 April. Retrieved from http://tass.com/economy/786472.

Tepavcevic, S. (2013). Russian Foreign Policy and Outward Foreign Direct Investments: Cooperation, Subordination, or Disengagement? Ph.D. Dissertation. Budapest: Central European University. Retrieved from http://www.etd.ceu.hu/2014/tepavcevic_sanja.pdf.

The Slovenia Times. (2012). Terme Maribor Sold to Russians. 2 April. Retrieved from http://www.sloveniatimes.com/terme-maribor-sold-to-russians.

UNCTAD. (2015). World Investment Report 2015: Reforming International Investment Governance. New York/Geneva: United Nations.

UNCTAD. (2016). World Investment Report 2016: Investor Nationality: Policy Challenges. New York/Geneva: United Nations.

UNCTAD. (2017). World Investment Report 2017: Investment and the Digital Economy. New York/Geneva: United Nations.

UNCTAD. (2019). World Investment Report 2019: Special Economic Zones. New York/Geneva: United Nations.

UNCTAD FDI Database. (n.d.). Retrieved from http://unctadstat.unctad.org/wds/ReportFolders/reportFolders.aspx.

Vahtra, P., \& Liuhto, K. (2004). Expansion or Exodus? Foreign Operations of Russia's Largest Corporations. Electronic Publications of Pan-European Institute, No. 8/2004.

Vasileva, A. (2014). Continuity and Change in Russian Capitalism. In U. Becker (Ed.), The BRICs and Emerging Economies in Comparative Perspective: Political Economy, Liberalisation and Institutional Change (pp. 100-122). Abingdon: Routledge.

Warga, Ž. (2007). The Slovenian Steel Industry: One of the Pillars of the High-Tech Society. sinfo, 6, 21-24.

Weiner, C. (2006). Russian FDI in Central and Eastern European Countries: Opportunities and Threats. Working Papers, No. 168. Budapest: Institute for World Economics, Hungarian Academy of Sciences. Retrieved from http://real.mtak.hu/80460/.

wnp.pl. (2014). Luxoft zatrudni ok. 600 informatyków w Krakowie i Wrocławiu. 4 December. Retrieved from https://www.wnp.pl/tech/luxoft-zatrudni-ok-600-informatykow-w-krakowie-iwroclawiu,239874 1 _ 0 _ 0. html. 
Csaba Weiner, Ph.D. is a senior research fellow at the Institute of World Economics of the Centre for Economic and Regional Studies in Budapest, Hungary, which he joined in 2003 after graduating with his bachelor's degree in 2000 and master's degree in 2003, both in economics. His main areas of research interest are the energy sector in Central and Eastern Europe and the countries of the former Soviet Union; foreign direct investment in and from Russia; the Russian economy; and Russian-Hungarian relations. Weiner holds his $\mathrm{PhD}$ in Regional Sciences in 2011 after defending his doctoral thesis entitled "The Position of the Russian Gas Industry in the World Economy and Its Influence on International Cooperation". In 2016, his proposal on "Central and East European Energy Security Concepts" led to him being awarded the János Bolyai Research Scholarship by the Hungarian Academy of Sciences for the period 2016-2019. Supported by the New National Excellence Program of Hungary's Ministry of Human Capacities, Weiner was a Bolyai+ Teaching and Research Scholar at the Budapest Business School University of Applied Sciences during the 2018-2019 academic year. He has authored more than 70 publications and has been a speaker at some 70 conferences and workshops. 